\title{
ローラの傾きによって生じるウェブの波しわシミュレーション （傾き角によるしわ数の変化および歪分布や位置の不整としわ発生の関連）
}

\author{
矢鍋 重夫*1，永澤 茂*2，金子 智*2
}

\section{Simulation of wavy wrinkling of web caused by roller tilt (Change of the number of wrinkles and causes of the onset of the wrinkling)}

\author{
Shigeo YANABE ${ }^{* 1}$, Shigeru NAGASAWA ${ }^{* 2}$ and Satoshi KANEKO*2 \\ ${ }^{* 1}$ Nagaoka University of Technology \\ 2-4-25 Settaya, Nagaoka-shi, Niigata 940-1105, Japan \\ ${ }^{* 2}$ Department of Mechanical Engineering, Graduate School of Engineering, Nagaoka University of Technology \\ 1603-1 Kamitomiokamachi, Nagaoka-shi, Niigata 940-2188, Japan
}

Received: 25 October 2017; Revised: 20 December 2017; Accepted: 22 February 2018

\begin{abstract}
This paper deals with the onset and development of wavy wrinkling of a web caused by a roller tilt using a FEM commercial software. The simulation model mainly used is composed of two rigid rollers and a web (a rectangular sheet) divided by a membrane element with four nodes. After applying tension to the web, both end parts of the web are fixed to the rollers and then the one roller is inclined gradually. The main results are summarized as follows. (1) The wavy wrinkling suddenly occurs at a tilt angle $\beta$ of the roller. A pitch, amplitude and slope of the wavy wrinkles are larger in the loose side of the web comparing with those in the tight side. The number of wavy wrinkles of the web decreases exponentially with increase in $\beta$. A slack area is approximately estimated as an area where the von Mises stress is smaller than a certain value. (2) The number of wavy wrinkles becomes larger when Young's modulus or a thickness of the web decreases, or when the web tension increases, comparing at the same $\beta$. (3) The onset of the wavy wrinkling is strongly affected by the imperfection of the tensile strain distribution and of the web position relative to the rollers in the tension process. (4) Another wavy wrinkling simulation method is proposed, which makes a membrane buckle by applying a small out-of-plane displacement.
\end{abstract}

Keywords: Simulation, FEM, Web handling, Membrane, Wrinkling, Roller tilt, Number of wrinkles, Tension

\section{1. 緒言}

ウェブと呼ばれるフィルムや連続紙の製造・加工ラインでは，ウェブの薄さや柔軟性のため様々な要因でしわ が発生する. 発生するしわの種類には, ローラ間を走行するウェブに生じる波しわ (wrinkle, wavy wrinkle, trough), ローラ通過時やニップ通過時に生じる折れしわ（wrinkle, folded wrinkle, crease), 巻き取られたロールのしわなど がある．波しわは，ウェブの幅方向の圧縮応力や面内のせん断応力によって生じる面外の弾性座屈で，そのまま で問題がない場合もあるが，波しわがローラ上で折れしわに発展する場合もある．折れしわは塑性変形をともな う場合が多く, ウェブの製品としての価值を著しく低下させる. 現場での経験から，波しわの発生原因として， (1)ローラの傾き（偏角），(2)ローラ形状（クラウン，逆クラウン，テーパー，曲り），(3)ローラのたわみ（自重や 張力による)，(4ウェブの厚さや張力の幅方向分布不均一，などが挙げられている(Eggen, 2011)。また，ローラ間 に生じるウェブの波しわを，しわの向きや対称性から 4 種類に分類し，その発生原因や低減策について記述した 文献もある(Roisum, 2008), (Smith, 2013). ローラ搬送されるウェブのしわに関しては Good らの研究(Good et al., 1997)がある. 彼らは, 薄いプラスチックフィルムを用いた実験から，折れしわの発生領域を示寸ローラ偏角〜張

No.17-00473 [DOI:10.1299/transjsme.17-00473], J-STAGE Advance Publication date : 6 March, 2018

*1 正員, 名誉員, フェロー, 長岡技術科学大学（广940-1105 新潟県長岡市摂田屋 2-4-25)

*2 正員, 長岡技術科学大学 大学院 機械創造工学専攻（广940-2188 新潟県長岡市上富岡町 1603-1）

E-mail of corresponding author: yanabe@nct9.ne.jp 
力図を作成するとともに，折れしわの発生限界に関する 2 式を導出した，ひとつは，波しわ発生の条件式で，口 一ラ偏角によるウェブのせん断荷重と張力を受けるウェブの幅方向座屈荷重を等置した式，もうひとつは，ロー ラに乗り上げた波しわがその形状を保持する条件式で， ローラ軸方向の摩擦力（張力に比例）とローラに巻き付 いたウェブの幅方向座屈荷重を等值した式である. 式の導出には多くの仮定があり，発生する波しわの形状に関 する記述もないが，二つの式は実験結果を比較的よく説明していると述べられている．筆者らのひとりは，FEM 汎用解析ソフトを用いて，ローラの傾きに起因する搬送中のウェブの横ずれ（ローラ軸方向へのずれ）挙動や波 しわが折れしわへ移行する過程をシミュレーションした(矢鍋，猪股，2007). 彼らはその中で，波しわがローラ に乗り上げると，しわで二分された領域の横ずれ速度の違いからしわ幅は狭くなり，しわ高さは高くなって，っ いには倒れて折れしわになることを示した，以上のように，ウェブハンドリングの分野では，ウェブの折れしわ に関していくつかの研究があるが, 波しわの発生やしわ数・しわ模様などについてはこれまであまり研究されて いないように思われる.

一方, 宇宙工学の分野では, 宇宙用アンテナなどの大型膜構造物の性能が膜のしわに影響されるため, 多くの 研究が行われてきた. 膜の波しわ解析の手法としては, (1)膜要素を用いた張力場理論, (2)シェル要素を用いた分 岐座屈解析や擬似分岐座屈解析がある. (1)の張力場理論は, 膜の曲げ岡性をゼロとし, 構成方程式に種々の修正 を加えて, 膜のしわやたるみの発生領域などを高精度で予測できるが, 波しわの詳細（振幅，波長，しわ数）に ついての情報は得られない，この点に関して，波しわによる面外変形の曲げ歪や膜の伸び歪によるエネルギの総 和を極小化することで, 一軸引張りを受ける矩形膜の波しわの波長や振幅を計算する式（しわ波長は膜の厚さと 長さの積の平方根に比例し, 伸び歪の $1 / 4$ 乗に逆比例する) を導出した研究 (Cerda et al., 2002, Cerda and Mahadevan, 2003), (Puntel et al., 2011)がある． (2)の分岐座屈解析は，FEM 汎用解析ソフト上で行われ，その概略は次のよう である．解析対象となる矩形膜などを曲げ岡性を持つ特製のシェル要素で分割し，面外座屈の引き金となる初期 不整（微小な面外変位）を膜面に付与する.この膜に伸び（張力）やせん断変形を徐々に増加させながら加え， 膜を面外座屈させる.さらに座屈後の分岐過程を計算し, 波しわの成長を調べる. Tessler ら(Tessler et al., 2003)は, 四辺形シェル要素を用い, 微小なランダム変位を初期不整として, せん断変形を受ける正方形膜などの波しわ成 長過程を計算した. 彼らは, 初期不整が膜厚の 1/100 1 の範囲でほぼ納得的なしわ振幅が得られると述べている. Diaby ら(Diaby et al., 2006)は, 曲げ岡性ゼロの膜要素を用いてせん断変形を受ける正方形膜のしわの成長過程を, 初期不整の導入なしに, 弧長法で解くプログラムを自作して計算している. Wong と Pellegrino (Wong and Pellegrino, 2002, 2006 a, 2006b, 2006c) は，せん断変形を受ける矩形膜の波しわに関して，一連の実験，理論解析，分岐座屈 解析を行い, せん断歪の増加と共にしわ数が段階的に増加すること, しわ数の増加（モードジャンプ）は最小主 応力の急増をともなうことなどを明らかにした．また， せん断変形で生じる波しわの形状を仮定し，主応力の面 外方向つりあい式などからしわの波長や振幅を推定する式を導出している. Zheng (Zheng, 2009)は, 一軸引張りを 受ける矩形膜の波しわについて実験および分岐座屈解析による計算を行い，伸び歪の増加に対してしわの振幅は 極大值をもつが，しわの波長は単調に減少する（しわ数は単調に増加する），しわ領域では最小主応力はゼ口を 中心に変動し, その極大極小は波しわの面外変位の極小極大に対応する, しわが最初に形成される膜の伸び歪を 正確に決めるのは困難である, などと述べている。こうした研究により, 現在ではしわの成長過程の計算手順が ルーチン化され，しわの詳細とその変化が明らかになりつつあるが，加えた初期不整が計算結果に大きく影響す ることに注意が必要のようである。 また，最初に波しわが発生する伸び歪やせん断歪の大きさについては，まだ あまり検討されていないように思われる.

本研究は, ウェブハンドリングの立場から, 張力付加後, ローラの傾き（偏角）によるウェブの波しわ発生過 程を FEM 汎用解析ソフトでシミュレーションし，その基本的な特性を明らかにしている．計算モデルは，4本ま たは 2 本の円筒剛体ローラと膜要素で分割したウェブ（矩形のシート）からなる. また，ブロックと矩形シート からなるモデルに面外変位を強制的に加えて波しわを発生させるシミュレーションも行った，その結果，ローラ 偏角の増加とともにしわ数が指数関数的に減少すること, 同じ偏角では張力が大きいほど, ウェブのヤング率や 厚さが小さいほど, しわの数が多いこと, 波しわが最初に発生する偏角はウェブの伸び歪分布の不整やウェブの 位置の不整によって大きく変わることなど, 新たな知見が得られたので, 以下に報告する. 


\section{4 ローラモデルによる波しわ発生シミュレーション}

\section{$2 \cdot 14$ ローラモデルとシミュレーション方法}

ウェブ搬送モデルとしてよく使われる 4 ローラモデル（図 1) において，ウェブに張力を加えたあと 1 個のロ 一ラの傾き角（偏角）を徐々に大きくしながら波しわの発生およびその変化過程を FEM 汎用解析ソフトでシミ ユレーションした. ここで用いた 4 ローラモデルは, 平行に配置した直径 $D=10 \mathrm{~mm}$ の 4 本の円筒ローラ(R1 R 4$)$ と, 長さ $140 \mathrm{~mm}$ ，幅 $W=20 \mathrm{~mm}$ ，厚さ $t=0.01 \mathrm{~mm}$ のウェブからなる. 円筒ローラは剛体面とし， ウェブは長方形 の 4 節点膜要素 $(1 \times 0.5 \mathrm{~mm})$ で長さ方向に 140 分割, 幅方向に 40 分割した. 座標系は, ウェブの搬送方向, 幅 方向をそれぞれ $\mathrm{x}$ 軸, $\mathrm{z}$ 軸，ウェブの面外変位の方向を $\mathrm{y}$ 軸にとる. 計算の手順を以下に示す (図 2(a) (d)参照). (1)4 本の平行なローラおよびウェブを, 図(a)の配置で作成する. (2)ウェブの両端の節点に微小な引張荷重を加え たのち, R1, R4 を-y 方向に $h$ 移動させる (図(b)). (3)ウェブの両端の節点すべてに既定の引張荷重 $t s n$ を $\mathrm{x}$ 軸方向 に加えて, ウェブに張力 $T(=41 \times t s n[\mathrm{~N}])$ を与える (図(c)). (4)R1, R3, R4 を固定し， R2 をウェブ幅方向の中心を通 り $\mathrm{y}$ 軸に平行な軸まわりに角度 $\beta$ 回転させて偏角 $(\beta)$ を与える. 偏角を計算の 1 ステップ当たり $0.05^{\circ}$ ズつ増加 させ，波しわの発生とその変化を調べる（図(d)）。波しわの全体的な特徴を把握するため，偏角 $\beta$ の最大值を $10^{\circ}$ とした.シミュレーションに用いたウェブの物性值や計算時のパラメータの值を表 1 に示す.計算では Large strain, Total Lagrange を指定するとともに, 分離条件は応力基準とし $0.1 \mathrm{MPa}$ を指定した. なお，摩擦力 $F$ は, $\mu, Q, V r, C$ を摩擦係数, 押付け力, すべり速度, 基準すべり速度 $(C=0.1 \mathrm{~mm} / \mathrm{s})$ として, 式(1)で計算している.

$$
F=\mu Q \frac{2}{\pi} \tan ^{-1} \frac{V_{r}}{C}
$$

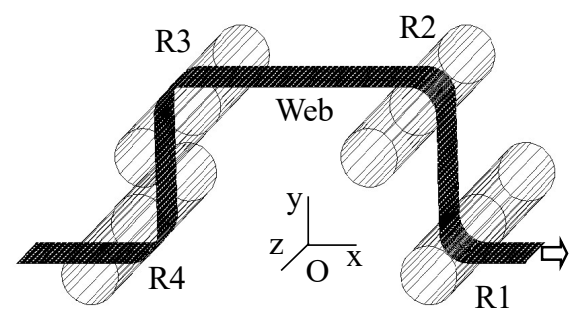

Fig.1 Four roller model for wrinkling simulation
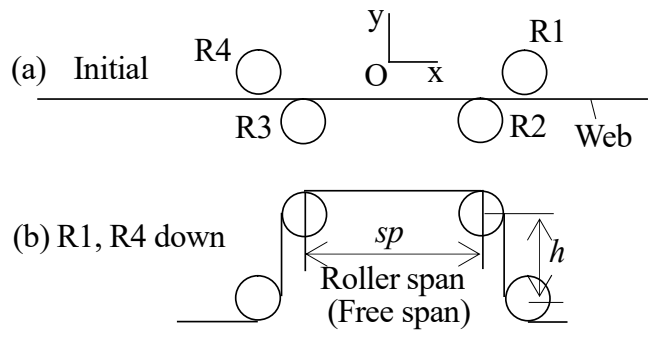

(c) Applying tension

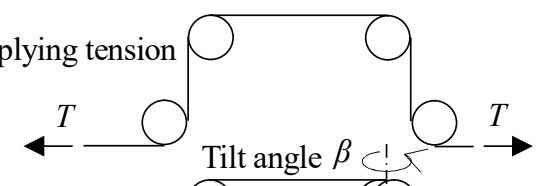

(d) Tilting R2

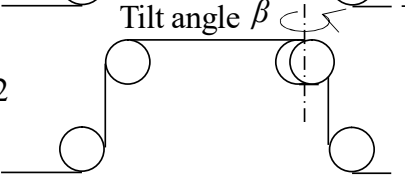

Fig.2 Simulation procedure of 4 roller model

\begin{tabular}{|l|l|l|l|l|l|l|l|l|}
\hline $\begin{array}{l}W \\
{[\mathrm{~mm}]}\end{array}$ & $\begin{array}{l}t \\
{[\mathrm{~mm}]}\end{array}$ & $\begin{array}{l}E \\
{[\mathrm{GPa}]}\end{array}$ & $v$ & $\begin{array}{l}s p \\
{[\mathrm{~mm}]}\end{array}$ & $\begin{array}{l}h \\
{[\mathrm{~mm}]}\end{array}$ & $\begin{array}{l}T \\
{[\mathrm{~N}]}\end{array}$ & $\mu$ & $\begin{array}{l}C \\
{[\mathrm{~mm} / \mathrm{s}]}\end{array}$ \\
\hline 20 & 0.01 & 1 & 0.3 & 40 & 20 & $0.05 \times 41$ & 0.3 & 0.1 \\
\hline
\end{tabular}

\section{$2 \cdot 2 \mu=0.3$ の場合のシミュレーション結果}

4 ローラモデルによる波しわ発生シミュレーションの代表例として $\mu=0.3$ の場合の結果について説明する. 図 3(a) (f)は, 張力付加後, R2 の偏角 $\beta$ を順次増加させた場合のウェブのしわの変化を示している. 図はy 軸上方 からウェブ面を見たもので，図(f)に示寸ように，右から 2 本目の傾いた R2 の軸と鉛直線のな寸角が偏角 $\beta$ であ る. $\beta(>0)$ の増加と共にフリースパン (R2, R3 の間) のウェブの上側が緩み側, 下側が張り側になる. 図では, しわ模様が見やすいようにウェブの面外（y 方向）変位を $0 \sim 1 \mathrm{~mm}$ の区間を 10 等分したグレー表示で示した. 面 外変位は小さいので, 正負でほぼ二值化され，明るい灰色部分が山（crest，手前に変位， $\mathrm{y}>0$ ), 暗い灰色部分が谷 (trough, $\mathrm{y}<0)$ になる. また, 図 3(c) ( f f については, 線分 $\mathrm{PQ} （$ フリースパン中央）に沿うウェブ面外変位の分 
布を図 4(a) (d)に示した. 図の横軸 $w_{z}$ は, ウェブの張り側（P）から緩み側（Q）へ向かって測った距離である. 図 3(a) $\beta=0$ では，ウェブの面外変位は直線で区分された灰色の明暗部分で表示されている．これは， R2, R3 間の ウェブが長手方向にわずかに傾いた平面と見なされる状態にあることを意味する．このウェブ面の傾きは, 要素 分割されたウェブが，両ローラに対して少し異なった折れ線形状で接触し，接触点近傍の節点の $\mathrm{y}$ 変位がわずか に異なる（R3 上で $-0.0025, \mathrm{R} 2$ 上で $0.0032 \mathrm{~mm}$ ）ことに起因する. $\beta$ が増加すると, $\mathrm{y}=0$ の境界線は少し湾曲し, その後, $\beta=1.5^{\circ}$ で境界はスパイク状のジグザグ形状になる（面外凹凸の発生）， $\beta=1.7^{\circ}$ 前後では, 図 3(b)のような

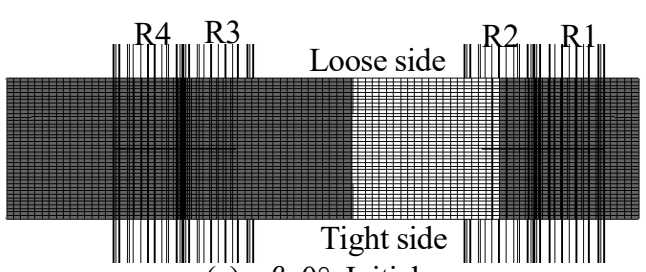

(a) $\beta=0^{\circ}$, Initial

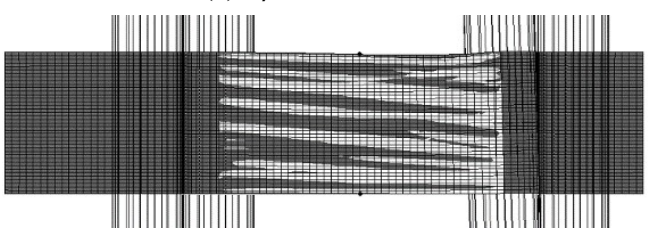

(b) $\beta=1.7^{\circ}$, Unclear wrinkling

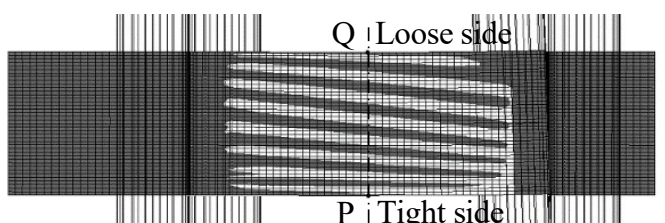

(c) $\beta=2^{\circ}, n=8$, Wavy wrinkling

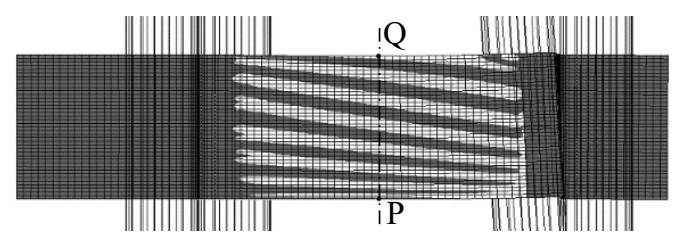

(d) $\beta=3.5^{\circ}, n=7.5$

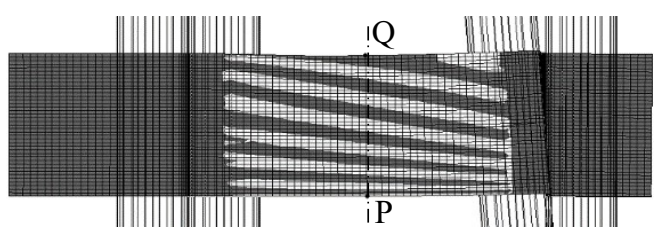

(e) $\beta=4.5^{\circ}, n=6.5$

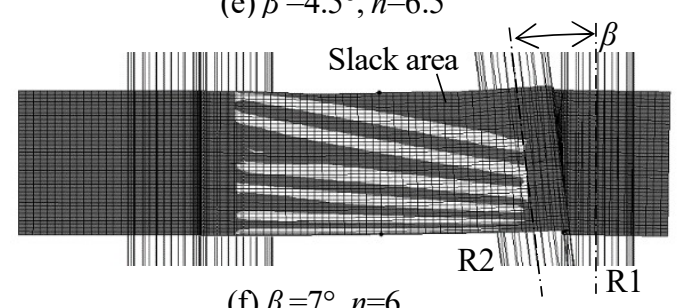

(f) $\beta=7^{\circ}, n=6$

Fig.3 There are several wrinkling patterns, such as no wrinkle, unclear wrinkling, and wavy wrinkling in case of $\mu=0.3$. The number of wavy wrinkles ( $n$ ) decreases with $\beta$. The wavy wrinkles incline against $\mathrm{x}$-axis and their slopes are larger in the loose side of the web comparing with in the tight side. A distance between wrinkles is larger in the loose side and normally increases with $\beta$.
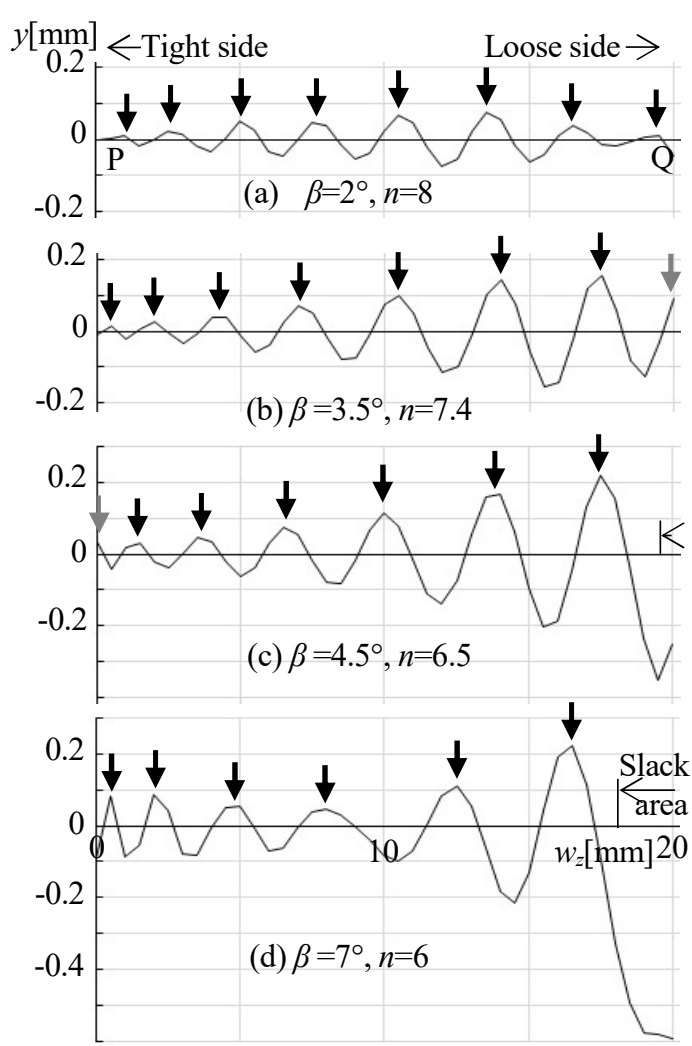

Fig.4 The number of wavy wrinkles decreases and the maximum amplitude of wrinkles increases with increase in $\beta$. Most of the wavy wrinkles move to the web edges and then disappear, as $\beta$ increases.

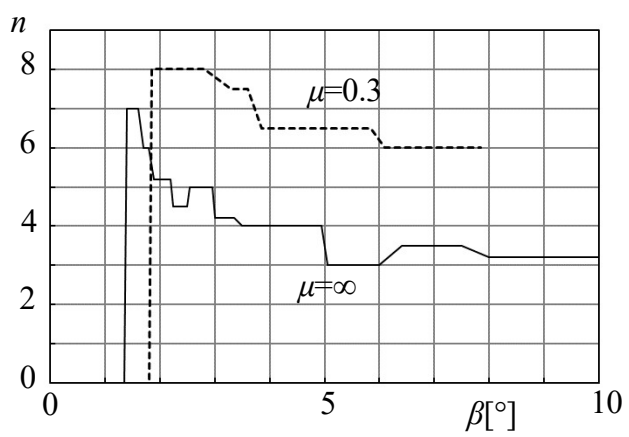

Fig. 5 The $n-\beta$ curve of $\mu=0.3$ shows that the wavy wrinkling with $n=8$ appears for $1.85^{\circ} \leq \beta \leq 2.8^{\circ}$, and $n=6.5$ for $3.85^{\circ} \leq$ $\beta \leq 5.85^{\circ}$. The $n-\beta$ curve of $\mu=\infty$ is situated lower than that of $\mu=0.3$. This difference is caused by the slip between the web and rollers. The slip makes $\beta$-effects smaller and delays the wrinkling pattern change. 
しわ数が数えられないしわ（形状不明なしわ）が形を変えながら現れる. $\beta=1.85^{\circ}$ 以降，図 3(c)のようなしわ数 8 本 $(n=8)$ の比較的明瞭な波しわが現れる. (1)波しわの 1 本 1 本は斜め右下方向を向くが，しわの傾きはウェブ の緩み側で大きく, 張り側の側端で小さい. (2)しわの間隔や振幅もウェブ緩み側で大きく, 張り側で小さいこと がわかる（図3(c)，図4(a)). (3) $\beta$ の増加と共に，通常，波しわはしわの間隔を広げながら，ウェブの側端へ向か って移動する. そのため, 側端に近いしわは一部が久落し, その後消滅する. また, 1 本のしわが途中で分岐す ることもあり，しわ数を小数点表示した場合やしわ数を決めにくい場合があった. 図 $3(\mathrm{~d})$ の $\beta=3.5^{\circ}$ では, しわ数 7.5 本の波しわが見られる. 図3(f)の $\beta=70$ では，しわ数 6 本の波しわとともに，ウェブの緩み側に大きな変位のた るみが生じている，たる久領域の山谷はしわ数には数えていない，以上の結果から，(4)偏角 $\beta$ が増加すると波し わの数が減少することがわかる. この場合 $(\mu=0.3)$ のローラ偏角 $\beta$ としわ数 $n$ の関係 $(n-\beta$ 線図と呼ぶ $)$ を示し たのが図 5 の破線である. 図中, $n=0$ 上の破線は，形状不明なしわが発生している範囲で，計算は $\beta=7.9^{\circ}$ で止ま っている. 張力付加中, ウェブにはしわは発生していない. $\beta$ 増加時, ウェブの張力（R2, R3 に作用する $\mathrm{x}$ 方向 の力）は $2.05 \mathrm{~N}$ から緩やかに増大し， $\beta=5^{\circ}$ で約 $12 \%$ 増加した. 張力の幅方向分布ついては 6 章参照.

\section{$2 \cdot 3 \mu=\infty$ 場合のシミュレーション結果}

摩擦を考慮した前節（4 ローラモデル， $\mu=0.3$ ) の場合， $\beta$ 増加時にウェブはローラ上ですべりを生じ，波しわ の発生やしわ数などに影響を与えていると思われる.ここでは, $\beta$ 増加時にウェブはローラ上ですべらない $(\mu=\infty)$ として波しわ発生のシミュレーションを行った，得られた結果を前節の場合と同様に整理し，結果の一部を図 6 , 図 7 に示す. また，この場合の $n-\beta$ 線図を先の図 5 に実線で示した．図 6,7 は, 2.2 節で述べた波しわの特徵(1) (4)を示している. 図 5 の 2 本の $n-\beta$ 曲線は，なめらかではないがほぼ右下がりの下に凸の曲線で， $\mu=\infty$ (すべり なし）の場合の方が $\mu=0.3$ （すべりあり）の場合より，しわ数 $n$ が少ない．これは，ウェブ・ローラ間にすべり があると $\beta$ 増加によるウェブ長手方向応力 $\sigma_{x x}$ の変化が緩和されてしわ数はあまり変化しないが, すべりがないと $\beta$ の増加はそのまま $\sigma_{x x}$ の変化となり, しわ数の大きな変化（減少）としてウェブに現れるためと思われる.

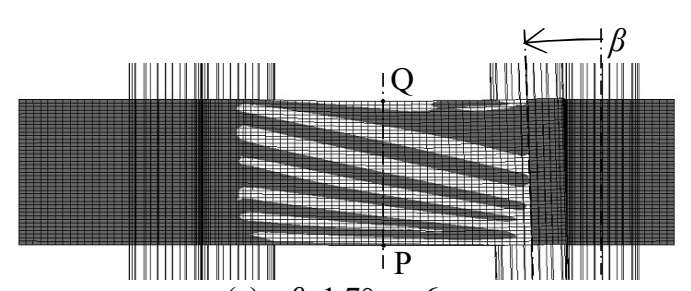

(a) $\beta=1.7^{\circ}, n=6$

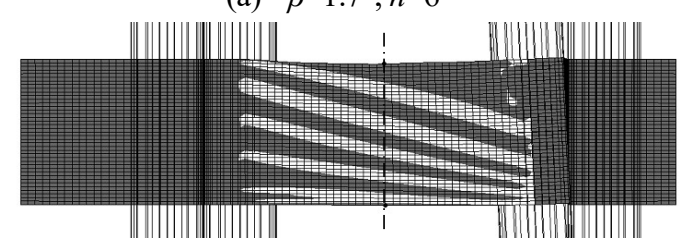

(b) $\beta=2.75^{\circ}, n=5$

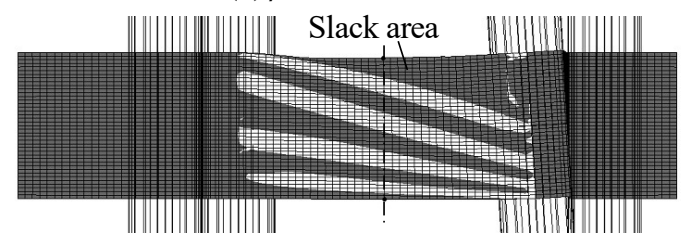

(c) $\beta=3.5^{\circ}, n=4$

Fig.6 These show the change of wavy wrinkling pattern due to $\beta$ in case of $\mu=\infty$. Characteristics of the wavy wrinkles are the same as those of $\mu=0.3$ in Fig.3.
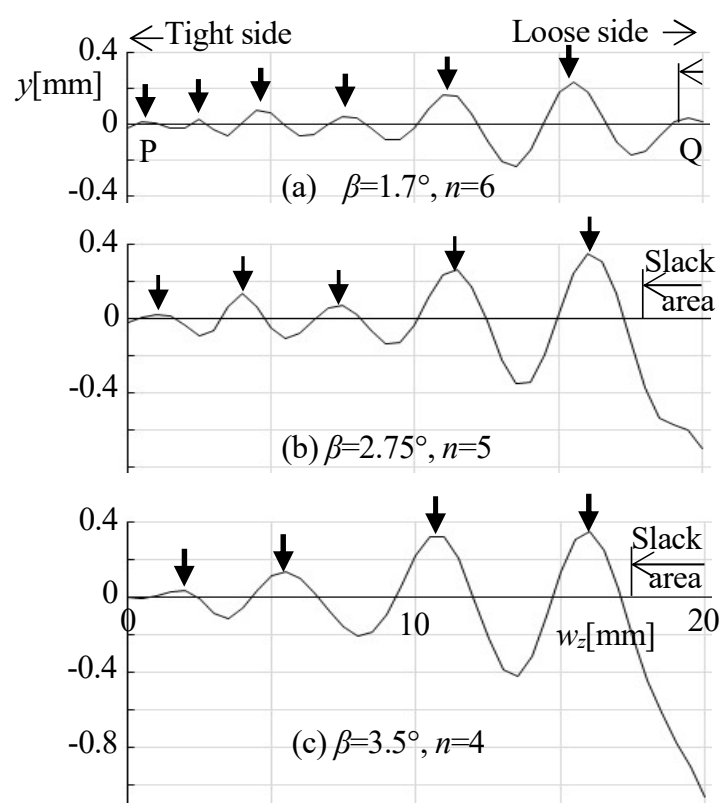

Fig.7 These show the change of wavy wrinkle profile due to $\beta$ in case of $\mu=\infty$. The number of the wrinkles is smaller and the amplitude is larger comparing with the case of $\mu=0.3$.

次章以降では, 広範囲の $\beta$ の值でしわシミュレーション結果が得られること, 計算時間が短いことを考慮して, $\beta$ 増加時のウェブ・ローラ間は固着 $(\mu=\infty)$ とし， 2 本のローラとウェブからなるより単純なモデルで, 波しわ発 生シミュレーションを行った. 


\section{2 ローラモデルによる波しわ発生シミュレーション}

\section{$3 \cdot 1 \quad 2$ ローラモデルとシミュレーション方法}

4 ローラモデルを簡略化した 2 ローラモデルを図 8 に示す. モデルは，直径 $D=10 \mathrm{~mm}$, 長さ $100 \mathrm{~mm}$ の 2 本の 平行円筒ローラ（ローラスパン $s p=40 \mathrm{~mm}$ ） と, 長さ $48 \mathrm{~mm}$, 幅 $W=20 \mathrm{~mm}$, 厚さ $t=0.01 \mathrm{~mm}$ のウェブからなる. 座標系は 4 ローラモデルの場合と同じで，ウェブは 4 節点膜要素 $(0.5 \times 0.5 \mathrm{~mm})$ で長手方向に 96 分割，幅方向に 40 分割されている. シミュレーションの手順は以下の通りである (図 9(a) (c)参照). (1)2 本の平行なローラ R1, R2 およびウェブを, 図(a)のような配置で作成する. (2)ウェブの両端の節点すべてに荷重 $t s n(=0.05 \mathrm{~N})$ を $\mathrm{x}$ 軸方向に加 えて，ウェブに張力 $T(=t s n \times 41)$ をえる（図(a)).このとき，ウェブ両端の幅方向（z方向）変位は自由とし， 拘束しない. (3)張力を加えたまま, ウェブの両端を下方（-y 方向）へ移動させ， ウェブ両端部を R1, R2 に固着さ せる $(\mu=\infty$, 図(b)). (4) R1 を固定し, R2 を $\mathrm{y}$ 軸まわりに角度 $\beta$ 回転させて偏角 $\beta$ を与え, ウェブに生じる波しわ

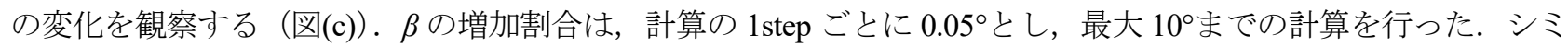
ユレーションに用いたウェブの寸法，物性值，計算時のパラメータの值を表 2 に示す. 表 2 の值は表 1 の 4 ロー ラモデルの場合と同じで，計算では，Large strain, Total Lagrange, 分離条件は応力基準で $0.1 \mathrm{MPa}$ を指定した.

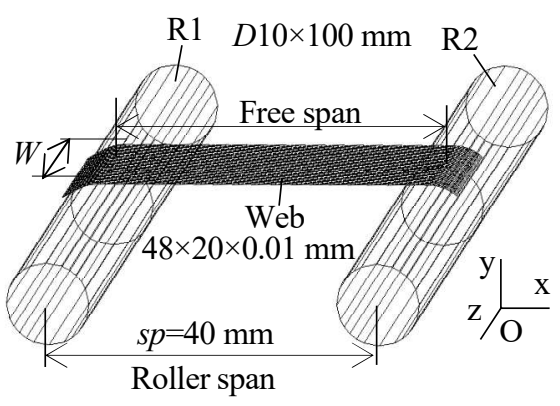

Fig.8 Two roller model for wrinkling simulation

Table 2 Main parameter values

\begin{tabular}{|l|l|l|l|l|l|l|}
\hline $\begin{array}{l}\beta \\
\left.{ }^{\circ}\right]\end{array}$ & $\begin{array}{l}s p \\
{[\mathrm{~mm}]}\end{array}$ & $\begin{array}{l}W \\
{[\mathrm{~mm}]}\end{array}$ & $\begin{array}{l}t \\
{[\mathrm{~mm}]}\end{array}$ & $\begin{array}{l}E \\
{[\mathrm{GPa}]}\end{array}$ & $v$ & $\begin{array}{l}T \\
{[\mathrm{~N}]}\end{array}$ \\
\hline $0-10$ & 40 & 20 & 0.01 & 1 & 0.3 & $0.05 \times 41$ \\
\hline
\end{tabular}

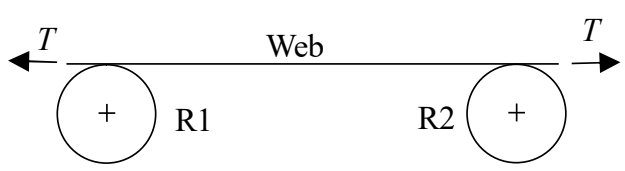

(a) Initial state and applying tension

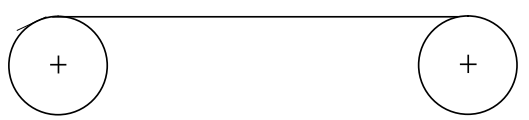

(b) Web ends down and fixed to rollers

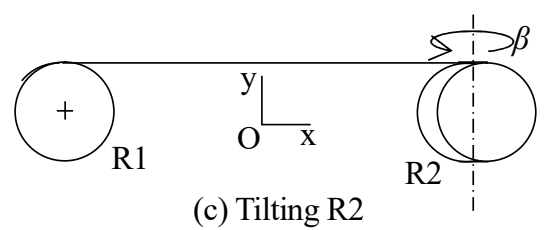

Fig.9 Simulation procedure

\section{3·2 2 ローラモデルによるシミュレーション結果の代表例 (Case A)}

2 ローラモデルのシミュレーション結果から, $\beta$ の増加によるウェブの波しわ模様や波しわ形状 (ウェブの面外 変位）の変化を抽出し, 結果を図 10, 図 11 に示した. これらの結果は, 基本的に, 2.2 節の図 3, 4 や 2.3 節の図 6,7 の結果（4 ローラモデル） と同じ傾向を示しているが，図 $10,11(\mathrm{a})$ では $\beta$ のかなり小さな值 $\left(0.65^{\circ}\right)$ で $n=9$ の波しわが生じていること, 図 $10(\mathrm{e}),(\mathrm{f})$ の $\beta=3^{\circ}, 10^{\circ}$ では, ウェブの緩み側で大きなたるみが生じている点などが 異なる.

(1) 波しわの傾きについて

波しわの傾きについては，2.2 節(1)で定性的な傾向について述べた. ここでは，図 10(b) $\beta=1 \circ の 7$ 本の波しわを 例にとり，個々のしわの傾きを定量的に調べた。 まず，(i) 1 本のしわに着目し，図(b)よりその傾きを読夕取る. 次に, (ii)そのしわ (扊色の帯状部分) の中心線とフリースパン中央の線 PQ との交点に一番近い節点の 3 応力 $\sigma_{x x}$, $\sigma_{z z}, \tau_{x z}$ から最大主応力の方向を計算する. 図 $10(\mathrm{~b}) \beta=1^{\circ} の 7$ 本の波しわを, 張り側側端から順に $1,2,3, \ldots, 7$ と番 号付けし，上記(i)，(ii)の結果を比較したのが表 3 である. 表より，両端のしわを除けば，(i)のしわの傾きは(ii) の最大主応力の方向にほぼ一致していること, しわの傾きはウェブの緩み側で大きく（最大で約 $9^{\circ}$ ), ウェブ張

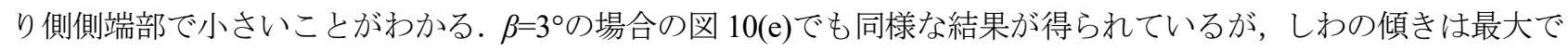
17 とかなり大きくなっている. 


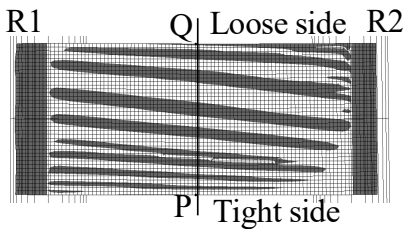

(a) $\beta=0.65^{\circ}, n=9$

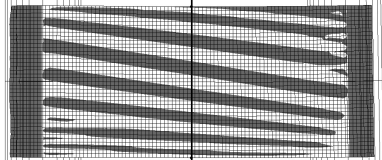

(b) $\beta=1^{\circ}, n=7$

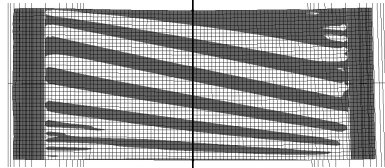

(c) $\beta=1.5^{\circ}, n=6$

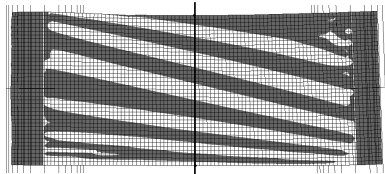

(d) $\beta=2^{\circ}, n=5.5$

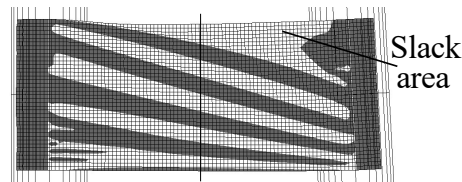

(e) $\beta=3^{\circ}, n=4$

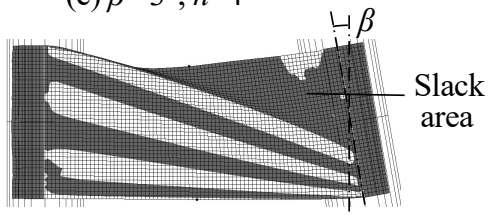

(f) $\beta=10^{\circ}, n=3.2$

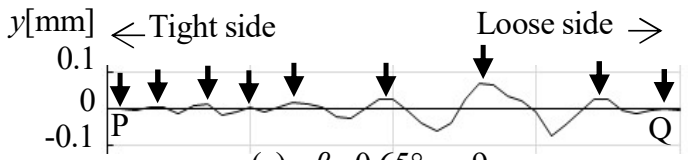

(a) $\beta=0.65^{\circ}, n=9$

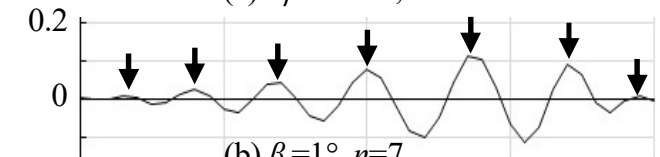

(b) $\beta=1^{\circ}, n=7$
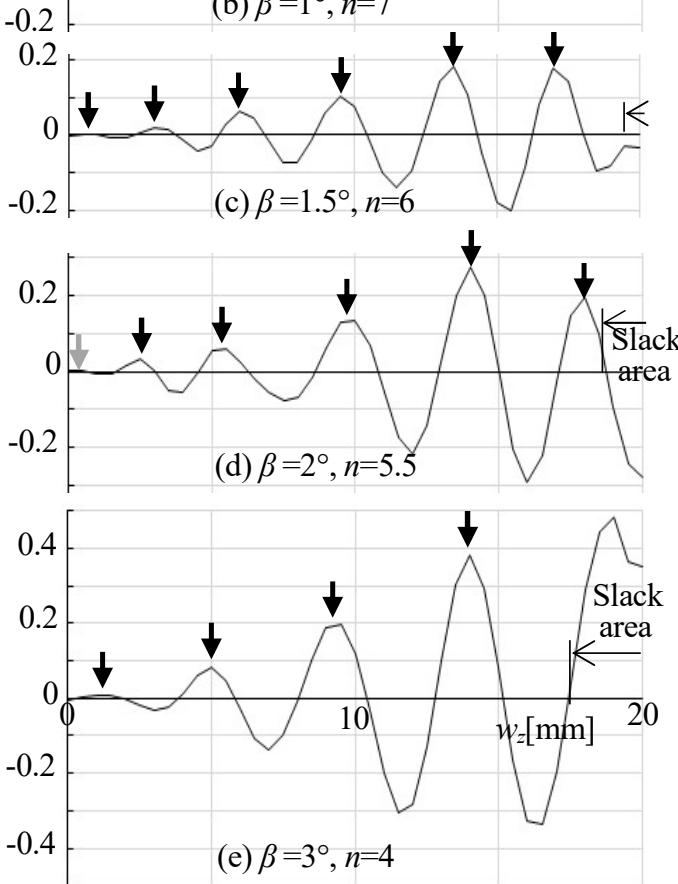

Fig.11 These figures show a development of the wavy wrinkle profile of 2 roller model $(\mu=\infty)$ with increase in $\beta$. The number of wavy wrinkles decreases and the maximum amplitude increases with $\beta$ as explained in Figs. 3 and 6.

Fig.10 These figures show a development of the wavy wrinkling pattern of 2 roller model $(\mu=\infty)$ with increase in $\beta$. The number of wavy wrinkles decreases with $\beta$ as explained in Figs. 3 and 6. But there are a few differences. The first wavy wrinkling with $n=9$ occurs at $\beta=0.65^{\circ}$ (Fig. (a)) and a large slack area is observed at $\beta=3^{\circ}$ and $10^{\circ}$ (Figs. (e) and (f)).

Table 3 Comparison between wrinkle direction and maximum principal stress direction in case of Fig.10 (b)

\begin{tabular}{|l|l|l|l|l|l|l|l|}
\hline Wrinkle number & $1^{\text {st }}$ & $2^{\text {nd }}$ & $3^{\text {rd }}$ & $4^{\text {th }}$ & $5^{\text {th }}$ & $6^{\text {th }}$ & $7^{\text {th }}$ \\
\hline Direction of wrinkles in Fig.10(b) $\left.\quad{ }^{\circ}\right]$ & 2.82 & 5.02 & 7.14 & 8.75 & 9.03 & 6.53 & 3.54 \\
\hline $\begin{array}{l}\text { Direction of maximum principal stress } \\
\text { calculated from }\end{array} \sigma_{x x}, \sigma_{z z}, \tau_{x z} \quad\left[\begin{array}{l}\left.{ }^{\circ}\right] \\
\hline\end{array}\right.$ & & 4.83 & 7.44 & 9.02 & 9.14 & 6.64 & 1.72 \\
\hline
\end{tabular}

(2) ウェブのたるみ領域について

図 3,6,10 に見られるように，ローラの偏角が大きくなるとウェブの緩み側（フリースパンの右上部）でたるみ が生じ，たるみの領域は次第に拡大する，たるみの発生とたるみの領域は，主観的に判断されることが多い。 こ こでは，ウェブの等価 von Mises 応力 $\sigma_{v m}$ に着目し, $\sigma_{v m} \leq 2 \mathrm{MPa}$ の領域とウェブがたるんでいると思われる領域 (た るみ領域）の重なりを調べた。図 $10(\mathrm{e}) \beta=3^{\circ}$ の場合について， $\sigma_{v m} \leq 2 \mathrm{MPa}$ の領域を図示したのが図 $12(\mathrm{a})$ の明る 
い灰色部分で, 図中に 3 本の破線で示したほぼ直角三角形の内側の領域（直角を挟む 2 辺の長さは $x_{s}=29 \mathrm{~mm}, z_{s}=8$ $\mathrm{mm}$ ）になる. そこで，この直角三角形の斜辺上の 5 個の節点に・印を付し，これらの・印を図 10(e)の波しわ模 様に重ねたのが図 12(b)である. 図(b)より，・印は一番上の波しわのへこみ部分（黒の右下がりの部分）の境界付 近にほぼ並び，その上側の白い領域が+zに変位したたるみ領域と考えられる。これより， $\sigma_{v m}=2 \mathrm{MPa}$ をたるみ領 域の境界と考えると, 図 10 では, $\beta=1.09^{\circ}$ からたるみが発生し, 図(b) $\beta=1^{\circ}$ で $x_{s}=6 \mathrm{~mm}, z_{s}=1.5 \mathrm{~mm}$, 図(c) $\beta=1.5^{\circ}$ で

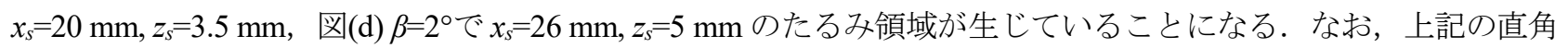
三角形の中に $2 \mathrm{MPa}<\sigma_{v m}$ の小さな領域が混じることもあった．他の計算結果についても調べたところ， $\sigma_{v m}=1$ ま たは $3 \mathrm{MPa}$ がたるみの境界にふさわしいような場合もあった。たるみ領域における 2 個の主応力（最大主応力， 最小主応力）の特徵については 6 章で説明する.

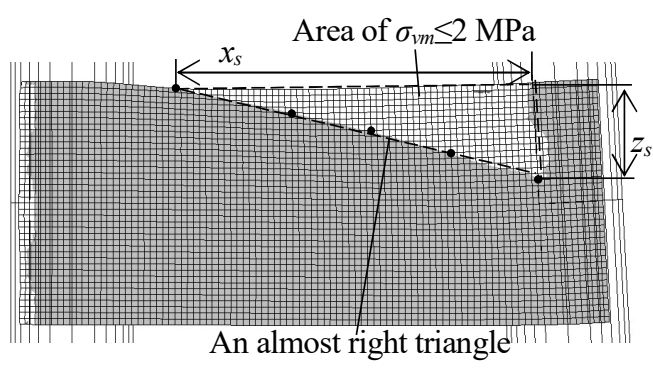

(a) Area of $\sigma_{v m} \leq 2$ and its boundary markers
The upper white part (a slack area)

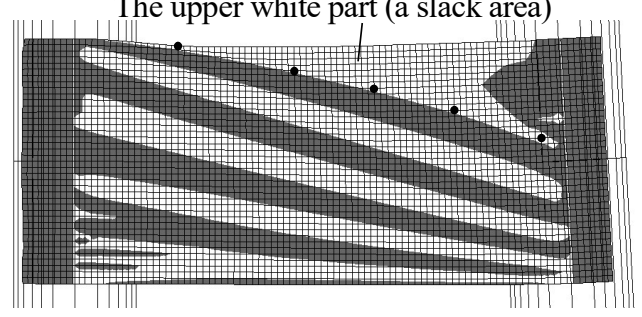

(b) Boundary markers on the wavy wrinkle pattern of Fig.10(e)

Fig.12 A light gray part in Fig.(a) indicates the area where the von Mises stress is not greater than $2\left(\sigma_{v m} \leq 2 \mathrm{MPa}\right)$. An almost right triangle which covers the light gray part seems to be a slack area of the web at this $\beta$. Five nodal points on the hypotenuse (the boundary of the slack area) are marked by small circles. In Fig. (b), these five nodal points are superimposed on the wavy wrinkle pattern at the same $\beta$. These points are situated around a boundary of the upper white part which seems to be a slack area.

次に，シミュレーション結果（図 $10,11 ）$ から $n-\beta$ 線図を作成した. 結果を図 13 に実線で示す. 同図には比較 のために，4 ローラモデルでローラ・ウェブ間固着の場合の結果（図 5 の実線 $\mu=\infty$ ） を破線で示した. 図 13 の 2 本の $n-\beta$ 線図は，波しわが最初に生じる $\beta$ の值や同じ $\beta$ でしわ数 $n$ の值が若干異なる点を除けば, ほぼ重なって いると考えられる。このことは，ウェブの幅や厚さ，物性值，ローラ間距離，張力などが同じであれば，4ロー ラモデルでなく 2 ローラモデルで波しわの特性が調べられることを示している. 次節では，2ローラモデルのシ ミュレーション結果を用いて，主要パラメータが波しわの $n-\beta$ 線図に及ぼす影響を調べる.

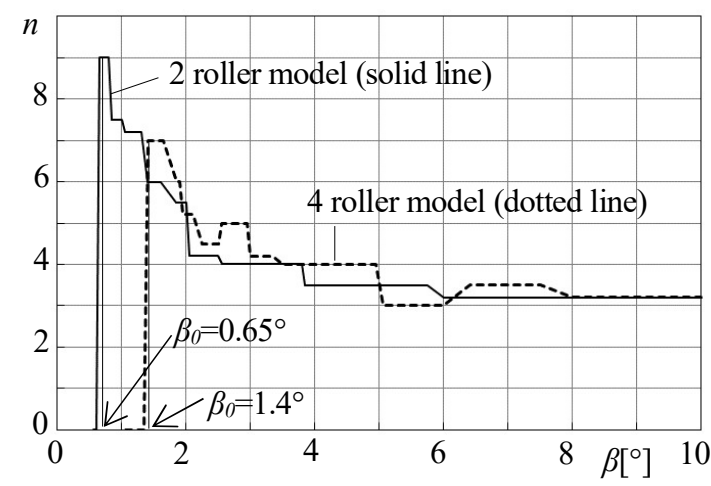

Fig.13 This figure shows a comparison between the $n-\beta$ curves of 2 roller and 4 roller models. Both curves are almost the same, as the main parameter values are the same. The figure indicates that the 2 roller model can be used to investigate characteristics of the wavy wrinkles instead of the 4 roller model. The onset tilt angle $\beta_{0}$ where the wavy wrinkle firstly occurs is smaller in the 2 roller model $\left(0.65^{\circ}\right)$ comparing with the 4 roller model $\left(1.4^{\circ}\right)$. 


\section{4. 主要パラメータが $n-\beta$ 線図に及ぼす影響}

表 2 に示したパラメータの值の組を基準として, 各パラメータの值を 2 通りに変えて波しわ発生シミュレーシ ヨンを行い， $n-\beta$ 線図を作成した．結果を図 14(a)-(f)に示寸. また，参考として，それぞれの場合について，張力 付加終了時におけるウェブ中央の節点の $\mathrm{x}$ 方向引張歪 $\varepsilon_{x x}$ の值を表 4 に示した. 表中の $n$ の闌には, パラメータご とに, 同じ偏角 $\beta$ におけるしわ数 $n$ の大小と増加方向（个, $\downarrow$ ）を示した。 - は明確な $n$ の変化がないことを表す.

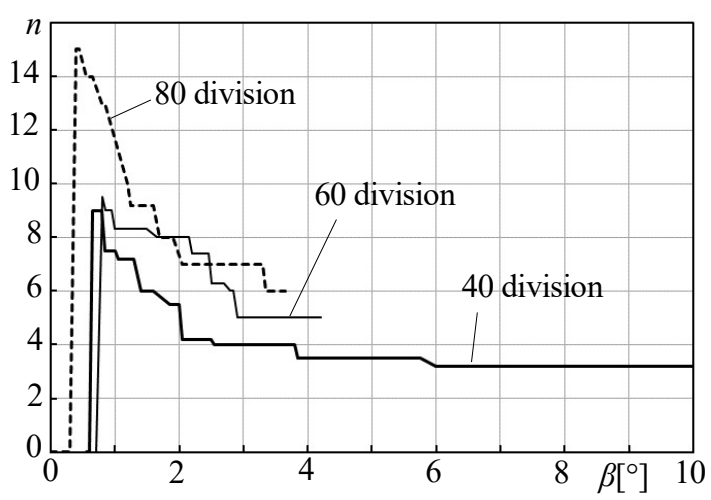

(a) Effect of the dividing number of the web width

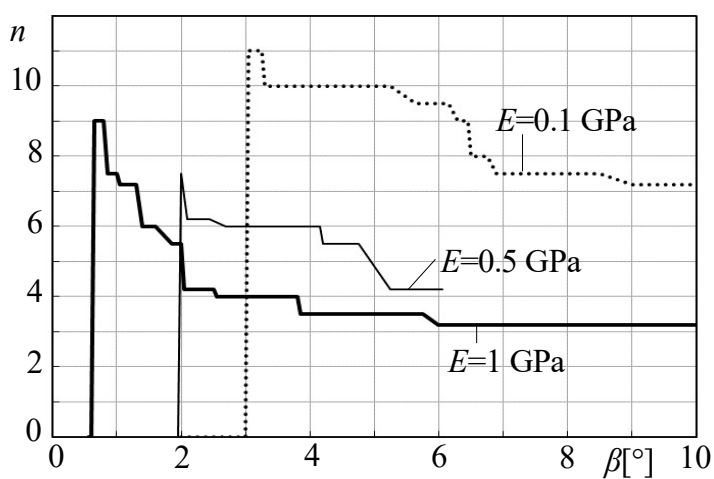

(b) Effect of Young's modulus $E$

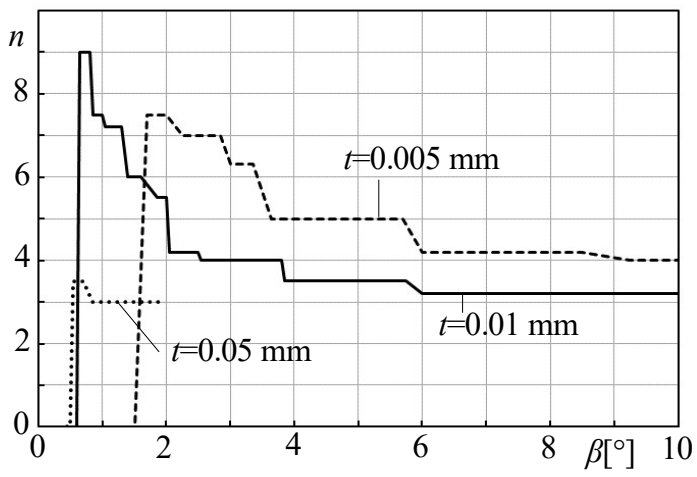

(c) Effect of web thickness $t$

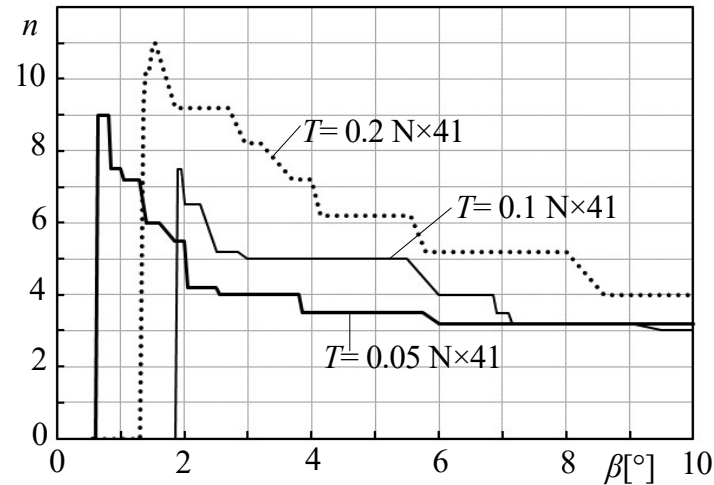

(d) Effect of web tension $T$

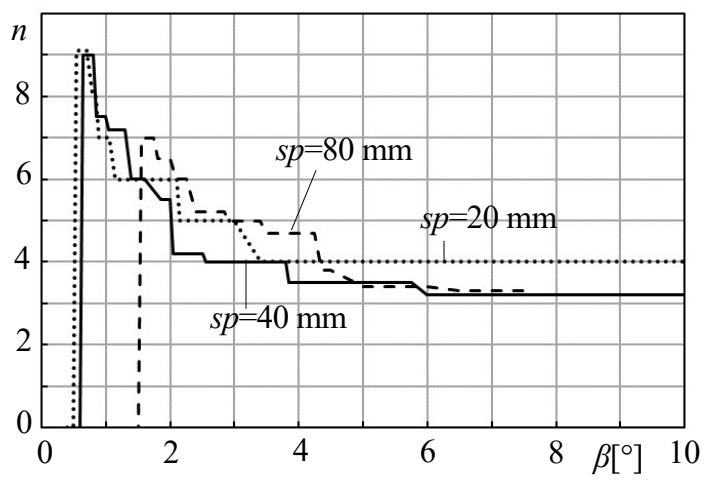

(e) Effect of roller span $s p$

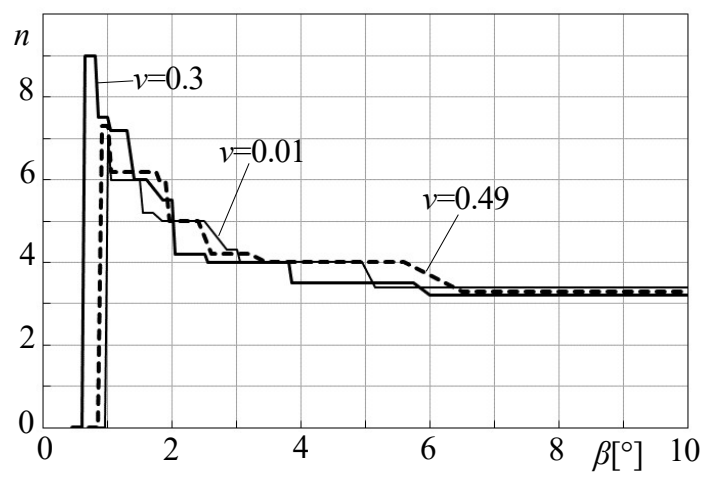

(f) Effect of Poisson's ratio $v$

Fig.14 Effects of the main parameters on the $n-\beta$ curve are shown here. Figure (a) shows the number of wavy wrinkles $n$ increases with increase in the number of elements dividing the web width. Figures (b) and (c) shows that $n$ becomes larger as the web Young's modulus $E$ or web thickness $t$ decreases comparing at the same $\beta$ value. $n$ becomes larger as the web tension $T$ increases (Fig.(d)). The roller span $s p$ and the web Poisson's ratio $v$ have little influence on the $n-\beta$ curve (Fig.(e), Fig.(f)). 
Yanabe, Nagasawa and Kaneko, Transactions of the JSME (in Japanese), Vol.84, No.859 (2018)

Table $4 \varepsilon_{x x}$ values of the web center node at the end of the tension process

\begin{tabular}{|c|c|c|c|c|c|c|c|c|c|c|c|}
\hline \multicolumn{2}{|c|}{ Parameters } & $\varepsilon_{x x}$ & $n$ & \multicolumn{2}{|c|}{ Parameters } & $\varepsilon_{x x}$ & $n$ & \multicolumn{2}{|c|}{ Parameters } & $\varepsilon_{x x}$ & $n$ \\
\hline \multirow{3}{*}{$\begin{array}{l}\text { Number } \\
\text { of div. }\end{array}$} & 40 & 0.010142 & small & \multirow{3}{*}{$\begin{array}{l}t \\
{[\mathrm{~mm}]}\end{array}$} & 0.005 & 0.020087 & large & \multirow{3}{*}{$\begin{array}{l}s p \\
{[\mathrm{~mm}]}\end{array}$} & 20 & 0.009985 & \\
\hline & 60 & 0.010142 & $\downarrow$ & & 0.01 & 0.010142 & $\uparrow$ & & 40 & 0.010142 & - \\
\hline & 80 & 0.010082 & large & & 0.05 & 0.002044 & small & & 80 & 0.010148 & \\
\hline \multirow{3}{*}{$\begin{array}{l}E \\
{[\mathrm{GPa}]}\end{array}$} & 0.1 & 0.093878 & large & \multirow{3}{*}{$\begin{array}{l}T \\
{[\mathrm{~N}]}\end{array}$} & 0.05 & 0.010142 & small & \multirow[t]{3}{*}{$v$} & 0.01 & 0.010147 & \\
\hline & 0.5 & 0.020087 & $\uparrow$ & & 0.1 & 0.020087 & $\downarrow$ & & 0.3 & 0.010142 & - \\
\hline & 1 & 0.010142 & small & & 0.2 & 0.039423 & large & & 0.49 & 0.010139 & \\
\hline
\end{tabular}

(1)ウェブの幅方向分割数がしわ数に及ぼす影響まず初めに, ウェブの幅方向分割数が波しわのしわ数 $n$ に及 ぼす影響を調べた．ウェブの分割要素の寸法を基準の $0.5 \times 0.5 \mathrm{~mm}$ から $0.5 \times 0.333 \mathrm{~mm}, 0.5 \times 0.25 \mathrm{~mm}$ に変更し，ウ エブの幅方向分割数を基準の 40 から 60,80 に増加させた．これにともない， ウェブ張力 $T(=t s n \times 41=0.05 \mathrm{~N} \times 41)$ が

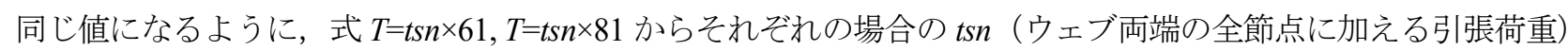
を $0.0336 \mathrm{~N}, 0.0253 \mathrm{~N}$ と求め, この值を用いてシミュレーションを行った. 得られた $n-\beta$ 線図が図 $14(\mathrm{a})$ である.

図より, ウェブの幅方向の分割数が増加すると, 発生する波しわの数 $n$ も増加すること, 波しわが最初に発生す る $\beta$ の值 $\left(\beta_{0}\right)$ は特定の傾向をもたないことがわかる. $n$ に関しては，分割数の多い方が正解に近いと思われる が, シミュレーション結果が得られる偏角 $\beta$ の上限が $4.2^{\circ}$ と小さく, しわ数の全体的な特徵を把握するのに不都 合であり, 計算時間も長い. 定量的な議論は今後の課題として, ここでは波しわの特徵（しわ数の定性的な変化） に着目することとして, ウェブ幅方向の分割数を 40 とした.

(2)ヤング率 $E$ の影響 $E$ の值を $1 \mathrm{GPa}$ から $0.5 \mathrm{GPa}, 0.1 \mathrm{GPa}$ に変更してシミュレーションを行った. それぞれ の場合の $n-\beta$ 線図を図 14(b)に示す. 図より, 同じ $\beta$ に対して $E$ の值が小さいほどしわ数 $n$ が大きいこと, $\beta_{0}$ の值 は，Eの值が大きいほど小さいことがわかる.

(3)ウェブ厚さ $t$ の影響 $\quad t$ の值を $0.01 \mathrm{~mm}$ に対して $0.005,0.05 \mathrm{~mm}$ と変えた場合の $n-\beta$ 線図を図 14(c) に示寸. $t$ $=0.05 \mathrm{~mm}$ の場合, $n$ が得られる $\beta$ の範囲が小さいが, 図より, $t$ の值が小さくなるにつれて $n$ が増加しているこ とがわかる. また， $\beta_{0}$ の值は， $t$ に対して特定の傾向をもたない.

(4)張力 $T(=t s n \times 41)$ の影響 張力の影響を図 14(d)に示す. 図より, $2^{\circ}<\beta<7^{\circ}$ の範囲では, 張力が大きいほどしわ 数 $n$ が大きいことがわかる. $\beta_{0}$ の值は, $T$ に対して特定の傾向をもたない.

(5)ローラスパン $s p$ およびポアソン比 $v$ の影響』これらの影響を図 14(e), (f)に示す. 図より, これらの值を変え てもあまり $n-\beta$ 線図は変化しないことがわかる.

また, 上記(2),(3),(4)の $E, t, t s n$ に関しては, 表 4 より, 「張力付加終了時のウェブの引張歪 $\varepsilon_{x x}(=\sigma / E=(T / A) / E=41 t s n$ $/(t W E))$ のきい方 $(E:$ 小, $t$ : 小, $t s n$ : 大）が, 偏角時のしわ数 $n$ が大きい」と言える. $s p$ やの影響が明確で ないのは，表 4 の $\varepsilon_{x x}$ の值がほぼ同じためであるが， $s p$ が上式に含まれていないことからも理解できる．ポアソ ン比 $v$ にいては, 張力付加時, ウェブ両端の幅方向変位を拘束していない（張力の増加に応じてウェブ両端の 幅が縮む）ため，その影響が小さいものと思われる.

図 14 のどの図においても $n-\beta$ 曲線は右下がりの下に凸の曲線である. $\beta$ の増加で $n$ が減少する明確な理由はわ からないが, (1) $\beta$ によるウェブの張力増加領域では, 曲げ岡性が高くなってしわ幅が大きくなり $n$ が減少するこ と, また, (2) $\beta$ によるウェブの張力減少領域では, たるみが生じてしわが発生するスペースが狭くなること, な どによるものかと思われる. なお, $\beta_{0}$ と主要パラメータ $t, t s n, v$ の定性的な関係は見出だせなかった.

\section{5. ウェブの伸び歪分布や位置の不整が波しわ発生開始の偏角 $\beta_{0}$ に及ぼす影響}

\section{$5 \cdot 1$ ウェブの伸び歪分布の不整の影響}

ウェブの寸法や物性值，境界条件や張力などパラメータの值が与えられれば，通常，ローラ偏角がある值 $\beta_{0} に$ 達したとき初めて波しわが発生し, パラメータの值を変更すれば, それに応じて $\beta_{0}$ が一定の傾向で変化する, と 思われる.しかしながら, 前章で述べたように, $\beta_{0}$ と主要パラメータの定性的な関係は, あまり見られなかった。 ここでは， ウェブの張力（ウェブ端の各節点に加えた引張荷重 tsnの和）は同じであるが，tsn の分布が異なるケ 
一スについて, 波しわの発生 $\left(n-\beta\right.$ 線図や $\beta_{0}$ など) がじのように変わるか, シミュレーションした. これまでは, ウェブ両端の全ての節点 (各端 41 節点) に同じ $t s n(=0.05 \mathrm{~N})$ を加え, 張力は $T=0.05 \mathrm{~N} \times 41$ であった (Case $\mathrm{A}$ と呼ぶ). 新たなケース（Case B と呼ぶ）では，この 41 節点のうちウェブの隅の 2 節点を除く 39 節点に同じ荷重 $t s n$ 'を加 え，隅の 2 節点にはそれぞれ $t s n^{\prime} / 2$ の荷重を加えた．この場合，張力は $T T^{\prime}=t s n^{\prime} \times 39+\left(t s n^{\prime} / 2\right) \times 2=t s n n^{\prime} \times 40$ になる.こ

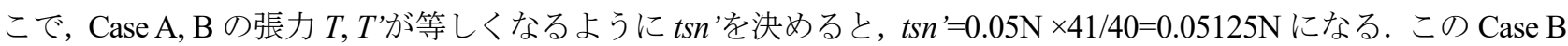
について, Case A（3.2 節の代表例）と同じ波しわ発生のシミュレーションを行った.

図 15(a), (b)に, Case A, B の張力付加終了時におけるウェブの $\mathrm{x}$ 方向の引張り歪 $\varepsilon_{x x}$ の分布を示す $\left(0.0098<\varepsilon_{x x}\right.$ $<0.0108$ の区間を 10 段階に分割してグレー表示). 両図のウェブ中央の節点の $\varepsilon_{x x}$ の值は $0.010142,0.010148$ とほと んど同じである. Case A の場合, フリースパン内ではほぼ $0.0098<\varepsilon_{x x}<0.0106$ で, ウェブの四隅の領域（図 $15(\mathrm{a}$ ) ○印）で $\varepsilon_{x x}$ の值が少し大きくなっている，一方，Case B では，ウェブ全面で $\varepsilon_{x x}$ は 0.010148 で一様であるが，ス ケールを拡大寸ると四隅（図 15(b)O印）の值がわずかに小さい. 以上より，Case B の $\varepsilon_{x x}$ 分布は極めて一様性が 高いと言える. ここでは, Case B のように, 張力付加終了時にウェブの $\varepsilon_{x x}$ がほぼ一様に分布している状態を, 張 力による伸び歪分布の不整が小さいと表現することにする．なお，不整とは，ある物理量の理想的な状態からの ずれを言う。

図 16(a)-(c)に Case B の代表的な波しわ模様を示寸.Case A については図 10 を参照．また，Case A, B の n- $\beta$ 線 図を図 17 に実線および破線でそれぞれ示す. 図 16(a) $\beta=2.8^{\circ}$ は, 形状の不明なしわが発生して 2 ステップ後の状 態で, 面外変位の大きさも極めて小さい $\left(0.03 \mathrm{~mm}\right.$ 以下). 図 16(b) $\beta=3^{\circ}$ は初めて現れたしわ数が数えられる波し わ $(n=5$, 最大振幅約 $0.3 \mathrm{~mm})$ で, これより Case B の $\beta_{0}$ は $3^{\circ}$ となり, Case A の $\beta_{0}=0.65^{\circ}$ と比へててかなり大きい. また, 同時にウェブの右上隅にたるみが生じている（3.2 節(2)で述べた $\sigma_{v m \leq} \leq 2$ の領域が存在する). 図(c) $\beta=5^{\circ}$ は計 算が停止した直前の波しわで, しわ数は $n=4$, しわの最大振幅は約 $0.6 \mathrm{~mm}$ である. 図ではわからないが, ウェブ 右上隅に大きなたるみ領域がある。計算停止の理由は不明であるが，たるみ領域の変位計算が収束しなかった可 能性が考えられる.

以上より, Case B のように張力による伸び歪分布の不整が小さいと，偏角 $\beta$ が大きくなるまで波しわは発生し ない $\left(\beta_{0}\right.$ が大きい). Case A, B の伸び歪の分布の不整の差はそれほど大きいとは思われないが，波しわが最初に 発生するローラ偏角 $\beta_{0}$ に大きな影響を及ぼすことは注目すべきことと思われる.

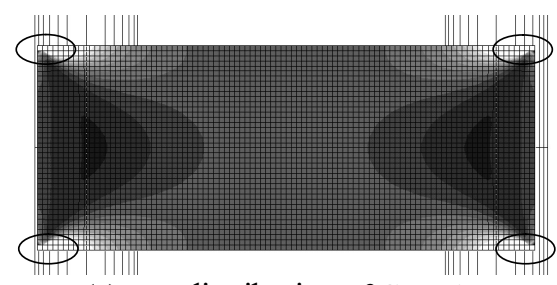

(a) $\varepsilon_{x x}$ distribution of Case A

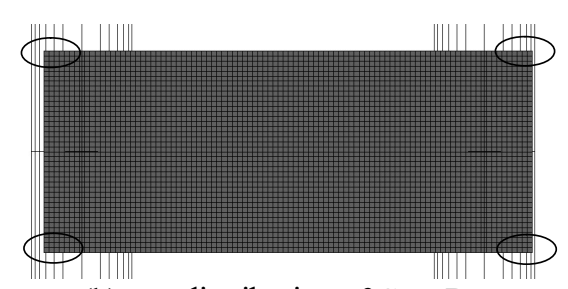

(b) $\varepsilon_{x x}$ distribution of Case B

Fig.15 These two figures show the elastic strain $\varepsilon_{x x}$ distribution just after applying tension to the web. In Case B, the $\varepsilon_{x x}$ distribution is uniform and has very little irregularity comparing with that of Case A, even though the $\varepsilon_{x x}$ value at each web center is the same. The Case B is called to have a small imperfection.

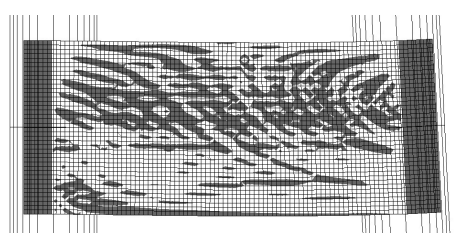

(a) $\beta=2.8^{\circ}, \mathrm{n}=-$

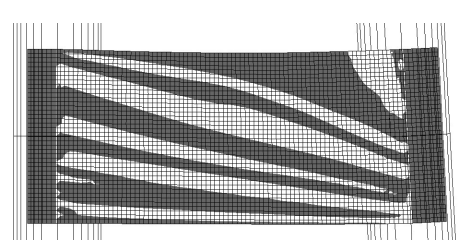

(b) $\beta=3^{\circ}, \mathrm{n}=5$

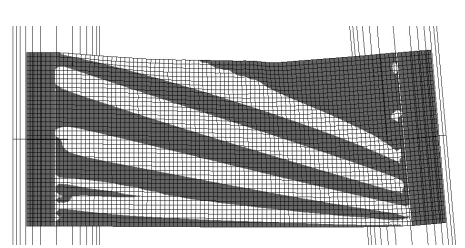

(c) $\beta=5^{\circ}, \mathrm{n}=4$

Fig.16 These figures show development of the wrinkling pattern in Case B due to $\beta$. Figure (a) shows an unclear wrinkling pattern, and Fig.(b) shows the first wavy wrinkling, which has five wrinkles $n=5$. Then the onset tilt angle $\beta_{0}$ of the Case $\mathrm{B}$ is $3^{\circ}$. Figure (c) shows the wavy wrinkling pattern just before the calculation stops. 


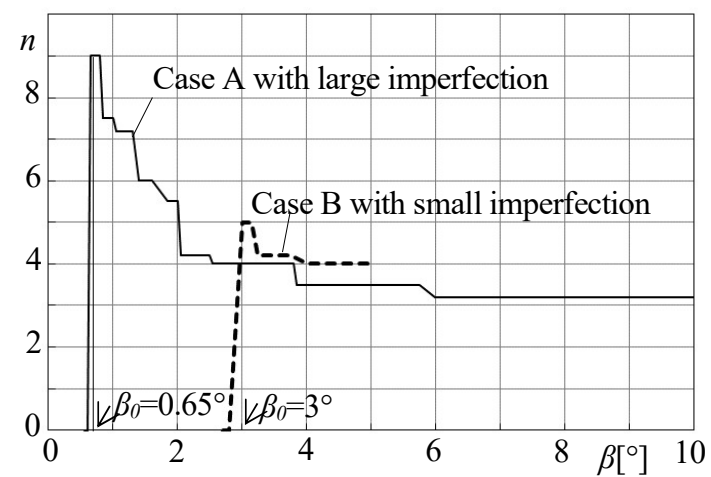

Fig.17 This figure shows the comparison of the $n-\beta$ curves between the Case A and B. In Case B which has a small imperfection, the wavy wrinkling occurs at larger $\beta$ value $\left(\beta_{0}=3^{\circ}\right)$ and disappears at smaller $\beta$ value $\left(5^{\circ}\right)$, comparing with the Case A with a large imperfection. $n$ of Case $\mathrm{B}$ is almost the same as that of A.

\section{$5 \cdot 2$ ウェブの位置不整の影響}

これまでのシミュレーションでは，ウェブ両端の節点に $\mathrm{x}$ 方向の引張荷重を加える際，それらの節点の $\mathrm{y}$ 方向 変位（面外変位）だけをゼロに拘束し， $\mathrm{x}, \mathrm{z}$ 方向変位は拘束していない，そのため，引張荷重付加時に，ウェブ の中心は $\mathrm{x}$ (長手) 方向へ $0.502 \mathrm{~mm}, \mathrm{z}$ (幅) 方向へ $0.034 \mathrm{~mm}$ ほどずれる（位置の不整を生じる，Case B). そ こで, ウェブに引張荷重を加える際, ウェブ中心の節点の $\mathrm{x}, \mathrm{z}$ 方向変位をゼロに拘束し, ウェブの位置の不整を 抑えて波しわ発生シミュレーションを行った（Case C と呼ぶ）。その他の計算条件は Case B と同じである.

不整が極めて小さい Case C の計算結果を見ると， ウェブは $4.85^{\circ}<\beta<5^{\circ}$ で-0.001 0.0015mm の微小な面外変位を 生じ， $\beta=5.1$ ○で図 18 に示すような形状不明なしわ（面外変位-0.03 0.036 mm）を生じて計算が停止した. このし わ模様は，Case B の波しわ発生前のしわの模様（図 16(a)）に似ている. 計算の刻みを細かくしても，しわ数を数 えられるような波しわは発生しなかった。

以上, Case A, B, Cの結果より，引張荷重を受けたのちローラの偏角によって生じる波しわは，引張荷重付加時 のウェブの伸び歪分布や位置などの不整が大きいと小さな偏角で発生し，不整が小さいと大きな偏角まで波しわ は発生しないと考えられる，不整が極めて小さいと形状不明で面外変位の極めて小さなしわは生じるが，その後 すぐに計算が停止し，波しわは発生しなかった.

これらのことから，張力を受けたあとローラの偏角によって生じる波しわの発生に関しては，次のように考え られる. すなわち,「ウェブの寸法や物性值, 境界条件や張力などが与えられた場合, ローラが特定の偏角に達し たとき波しわが発生するのではなく，ウェブの伸び歪分布や位置など計算時の種々の不整（理想的な值からのず れ）によって，波しわが最初に発生するローラの偏角 $\beta_{0}$ が決まる.（偏角が決まれば波しわの数が決まる.）不整 が極めて小さいと面外座屈を引き起こす作用が小さいため, 波しわは発生しない.」現在のところ, この不整の量 を測る物理量は見い出せていない.

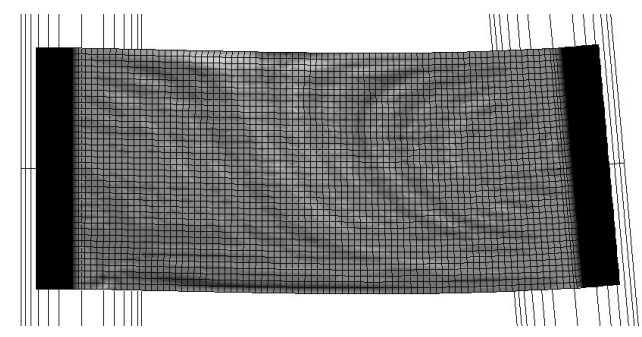

Fig.18 This figure shows the unclear wrinkling pattern of the Case $\mathrm{C}$ when the simulation stops $\left(\beta=5.1^{\circ}\right)$. The $\mathrm{Case} \mathrm{C}$ has little imperfection and the wavy wrinkling does not appear. This indicates that the imperfection in both the web tensile strain distribution and the web position against the rollers has a great influence on the occurrence of the wavy wrinkle. 


\section{6. しわ・たるみ発生時の主応力の幅方向分布}

矩形膜の 1 軸引張りや単純せん断などに関するこれまでの研究から, ウェブが張り (taut), しわ (wrinkled), たるみ (slack) の状態にあるときの主応力や主歪の状態がまとめられており, 主応力に関しては, $0<\sigma_{l}, \sigma_{2}$ (張り), $0<\sigma_{1}, \sigma_{2}<0$ (しわ)， $\sigma_{1}<0, \sigma_{2}<0$ (たるみ) とされている(例えば, Rabinskiy et al., 2016). ここでは, こうした規準が， 本シミュレーションの結果でも成り立っているか，前章の Case A, B の場合について調べた．なお，ここで図示 した主応力の幅方向分布は, 図 8 のフリースパン中央でなく, R2 から- $\mathrm{x}$ 方向へ $10 \mathrm{~mm}$ の位置でデータ採取した もので，最大主応力の幅方向分布は，ほぼ，張力の幅方向分布になっている.

\section{$6 \cdot 1$ 伸び歪分布の不整が大きい場合（Case A) の主応力分布}

この場合，ウェブは $\beta=0.65^{\circ}$ で初めて波しわを発生し， $\beta=1.09^{\circ}$ でたるみが発生しだす (3.2 節参照).そこで, 波しわ発生前 (張り状態), 波しわ発生後（しわ状態）, たるみ発生後（たるみ状態）の代表として $\beta=0.5^{\circ}, \beta=1^{\circ}$, $\beta=2^{\circ}$ を選び, ウェブの最大主応力 $\sigma_{1}$, 最小主応力 $\sigma_{2}$, 面外 (y 方向) 変位の幅方向分布を図 19(a) (c) に示した. $\sigma_{2}$ の值は $\sigma_{l}$ に比べてかなり小さいので，100 倍または 10 倍の值を図示した. また， $\beta$ にる $\sigma_{2}$ だけの変化をまとめ て図 19(d)に示した．図の横軸 $w_{z}$ は，ウェブの張り側から緩み側へ向かって幅方向に測った距離である.

図 19 より, 以下のことが言える. $\beta=0^{\circ}$ のさ，ウェブ全体は張り状態で， $\sigma_{l} \fallingdotseq 10 \mathrm{MPa}$ でウェブ幅方向に一定 (水平な直線, 図示していない)， $\sigma_{2}$ は幅中央で最大值 $0.073 \mathrm{MPa}$ の上に凸の山形の分布を示す (図(d)). $\beta$ が増 加すると， $\sigma_{1}$ は右下がりの直線になり傾きが次第に大きくなる． $\sigma_{2}$ は山形の高さが低くなり，さらにウェブの張 り側から負の領域が次第に広がる， $\beta=0.5^{\circ}$ で，ほぼウェブ幅の全体で $\sigma_{2}<0$ で下に凸の谷形の分布になっても，し

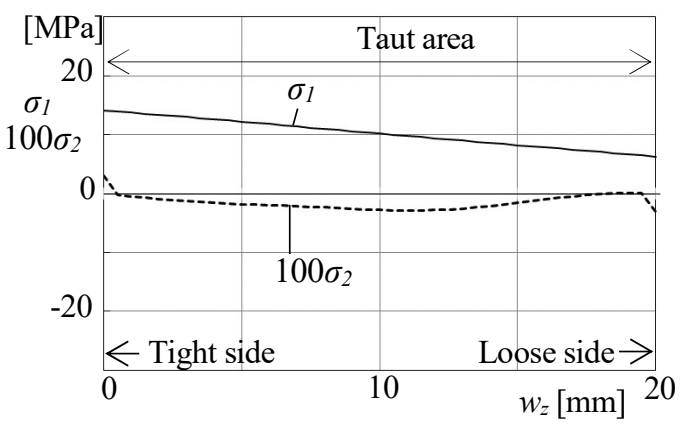

(a) $\beta=0.5^{\circ}$ before the wrinkle occurrence

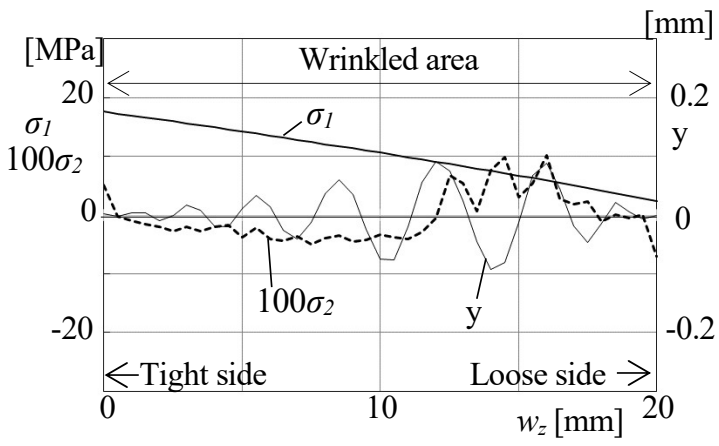

(b) $\beta=1^{\circ}$ after the wrinkle occurrence

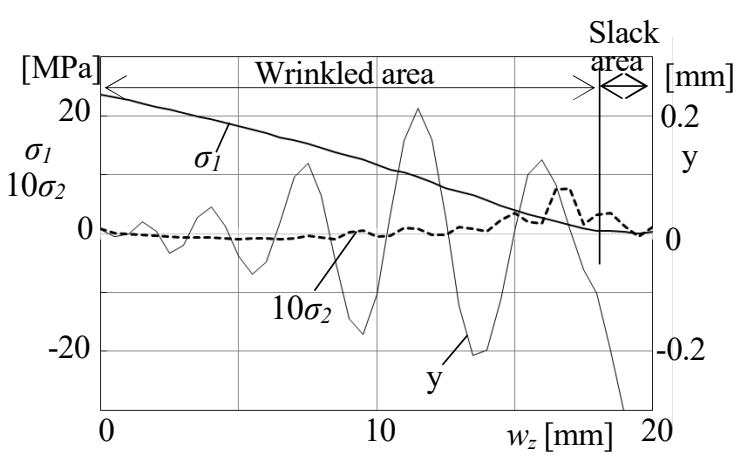

(c) $\beta=2^{\circ}$ after the slack area occurrence

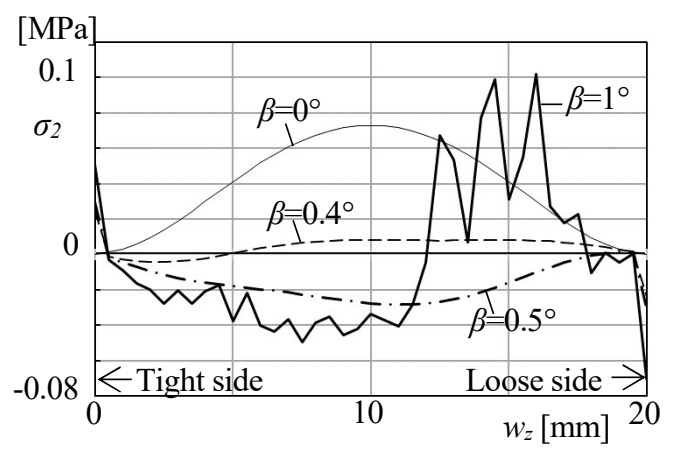

(d) $\sigma_{2}$ distribution before and after wrinkle occurrence

Fig.19 These figures show the distributions of the major and minor principal stresses $\left(\sigma_{1}, \sigma_{2}\right)$ in the taut, wrinkled and slack areas of the Case A with a large imperfection. As a reference, the out-of-plane displacement y of the wavy wrinkling is also shown. As $\sigma_{2}$ is very small comparing with $\sigma_{1}, \sigma_{2}$ is magnified and shown in each figure. Even though $\sigma_{2}$ is negative at $\beta=0.5^{\circ}$, the wavy wrinkling does not appear. And something exceeds a limit, the wavy wrinkling suddenly occurs and $\sigma_{2}$ distribution shows a complicated distribution as shown in Figs. (b) and (d). There seems no relation between $\sigma_{2}$ and $\mathrm{y}$. As $\beta$ increases further, the slack area gradually appears in the loose side of the web. In the slack area, both $\sigma_{l}$ and $\sigma_{2}$ are very small. $\sigma_{l}$ is always positive but $\sigma_{2}$ is not always positive. 
わは発生しない．波しわ発生中の図(b) $\beta=1$ ○では， $\sigma_{1}$ の分布形状はしわ発生前（図(a)）とあまり変わらず， $\sigma_{2}$ の分 布は大きく変化して, 張り側で負, 緩み側でほぼ正の鋸刃状の分布を示寸. なお， $\sigma_{2}$ としわ変位 $\mathrm{y} の$ 変動の山谷 には対応関係が見られなかった. $\beta$ がさらに大きくなり $\sigma_{l}$ の傾きが増えて右下がりの直線が右端でゼロ付近に達 するころから，ウェブにたるみ領域が現れ，次第にその領域が拡大寸る. たる久領域では, $\sigma_{1} \doteqdot 0, \sigma_{2} \doteqdot 0$ で $0<\sigma_{2}<\sigma_{I}$ の関係があった（図(c))．先に述べた従来結果と比較寸れば，本シミュレーションの結果では，(1) $\sigma_{2}<0$ になって もウェブは張り状態を保ち波しわが発生しなかったこと，(2)波しわが発生していてもウェブの緩み側では $\sigma_{2}>0$ の領域が広く存在していること, (3)たるみ領域では $\sigma_{1} \fallingdotseq 0, \sigma_{2} \fallingdotseq 0$ で $0<\sigma_{2}<\sigma_{1}$ の関係にあったことなど, いくつか の違いが見られた.

また, 図 19 の場合の最大主歪 $\varepsilon_{1}$, 最小主歪 $\varepsilon_{2}$ についても, 同様な検討を行った. 図は割愛するが, 従来の結 果と比較すると, $\varepsilon_{2}{ }^{\prime}=-v \varepsilon_{1}$ として, (1)張り状態では, $\varepsilon_{1}>0$ で $\varepsilon_{2}, \varepsilon_{2}{ }^{\prime}$ は負でほぼ等しく, 両端を除いて $\varepsilon_{2}<\varepsilon_{2}{ }^{\prime}<0$ であ ること, (2)しわ状態の $\varepsilon_{1}, \varepsilon_{2}, \varepsilon_{2}{ }^{\prime}$ の関係は張り状態のときとほとんど同じであるが, 緩み側で $\varepsilon_{2}>\varepsilon_{2}$ ' と逆転している 節点もあること, (3)たるみ領域では $\varepsilon_{1}, \varepsilon_{2}, \varepsilon_{2}$ は十分小さいが, $0<\varepsilon_{1}$ で, $\varepsilon_{2}$ は正負が混在していることなど，主応力 の場合と同様，違いが見られた。

\section{$6 \cdot 2$ 伸び歪分布の不整が小さい場合（Case B) の主応力分布}

この Case B では，ローラ偏角が $\beta=3^{\circ}$ のとき，突然ウェブは波しわとたるみを同時に発生する（5.1 節参照）. そこで, 波しわ発生前の張り状態として $\beta=1^{\circ}, \beta=2^{\circ}$, 波しわとたるみが同時に存在する状態として $\beta=3.5^{\circ}$ を選び, Case A（図 19）の場合と同様に, 最大主応力 $\sigma_{1}$, 最小主応力 $\sigma_{2}$, 面外（y 方向）変位の幅方向分布を図 20(a) (c) に示した．また， $\sigma_{2}$ だけの変化をまとめて図 20(d)に示した．同じローラ偏角 $\beta=1^{\circ}$ でも，不整が小さい図 20(a)で はウェブは張り状態にあり，一方，不整が大きい図 19(b)ではすでに波しわが生じている．両図の $\sigma_{l}$ の分布曲線 はほぼ同じであるが， $\sigma_{2}$ の分布曲線は大いに異なり，図20(a)から， $\sigma_{2}$ は負の領域にあってまだ下向きの湾曲を

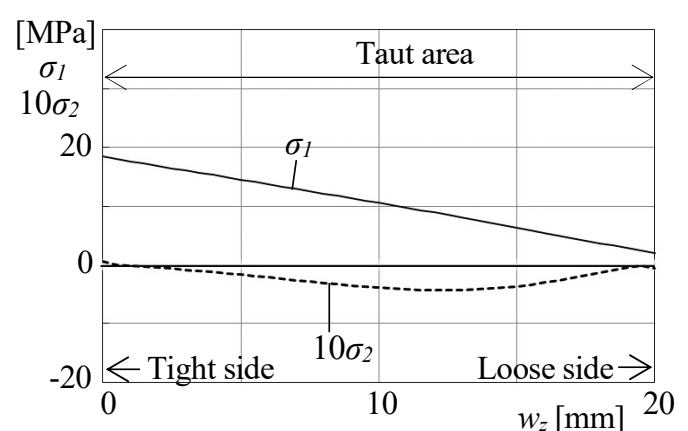

(a) $\beta=1^{\circ}$ before the wrinkle occurrence

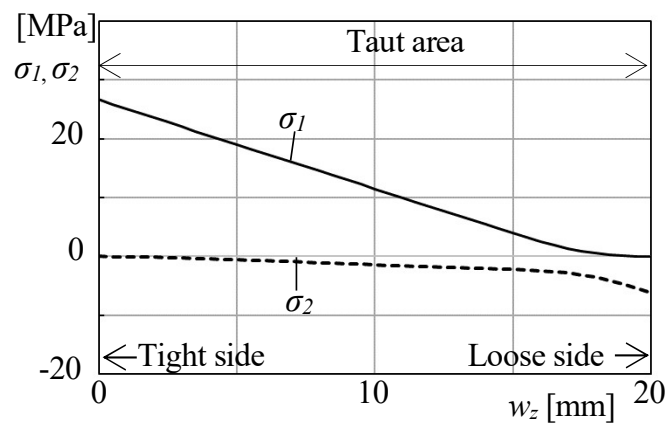

(b) $\beta=2^{\circ}$ before the wrinkle occurrence

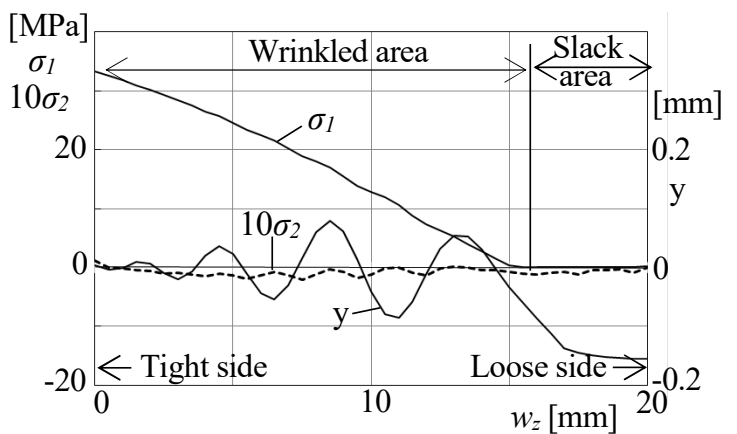

(c) $\beta=3.5^{\circ}$ after the wrinkle and slack occurrence

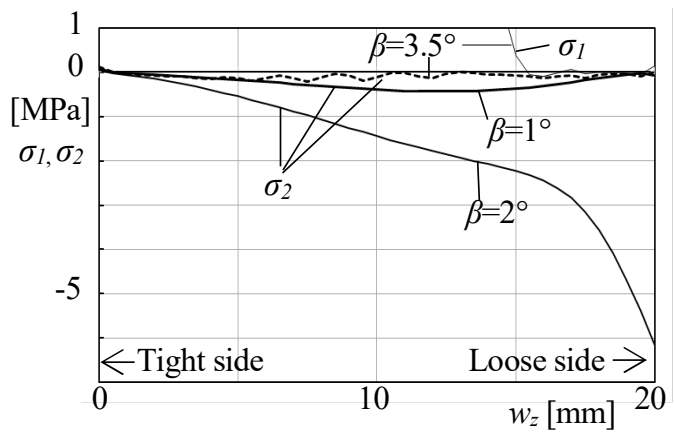

(d) $\sigma_{2}$ distribution before and after the wrinkle occurrence

Fig. 20 These figures show the distributions of the principal stresses $\left(\sigma_{1}, \sigma_{2}\right)$ in the taut, wrinkled and slack areas of the Case B with a small imperfection. In Figs. (a) and (b), both the wavy wrinkling and the slack area are not observed, even though $\sigma_{2}$ has a large negative value. $\beta$ further increases and something exceeds a limit, both the wavy wrinkling and the slack area suddenly appear at a time. In the wrinkled area, $\sigma_{1}$ is positive and $\sigma_{2}$ is negative and small. In the slack area, both $\sigma_{1}$ and $\sigma_{2}$ are very small. $\sigma_{2}$ is always negative but $\sigma_{1}$ is not always negative. $\sigma_{1}>\sigma_{2}$ is satisfied (see Fig.(d)). 
保っていることがわかる，ローラ偏角が $\beta=2^{\circ}$ のとき，不整が小さい図 20(b)ではウェブはまだ張り状態で， $\sigma_{1}, \sigma_{2}$ の分布曲線は，右下がりの直線とゼロを通る水平線を漸近線とする双曲線のような形状になる， $\sigma_{1}$ は正， $\sigma_{2}$ は負 でその絶対值は比較的大きい. $\beta=3^{\circ}$ で波しわとたるみが同時に発生し, $\beta=3.5^{\circ}$ のきの $\sigma_{1}, \sigma_{2}$ の分布曲線は, 図 $20(\mathrm{c})$ や図 20(d)のようになる. しわ領域では $\sigma_{1}$ は正， $\sigma_{2}$ は負でほぼゼ口に近い值で変動する．たるみ領域では， $\sigma_{1}, \sigma_{2}$ はほぼゼロで, $\sigma_{1}$ は正負混在しているが $\sigma_{1}>\sigma_{2}$ で $\sigma_{2}$ は負の状態にある. これらを従来の結果と比較すると, 以下 の点で異なる. (1) $\sigma_{2}<0$ でもウェブは張り状態を保ち波しわが発生しなかったこと, (2)たるみ領域では $\sigma_{1}, \sigma_{2}$ はほ ぼゼロで， $\sigma_{2}$ は負， $\sigma_{1}$ は正負混在しているが $\sigma_{1}>\sigma_{2}$ の関係にあった.

また，図には示していないが，本シミュレーションで得られた主歪 $\varepsilon_{1}, \varepsilon_{2}$ の特徵は, 以下の点で従来の結果と異 なる. ただし， $\varepsilon_{2}{ }^{\prime}=-v \varepsilon_{1}$ である. (1)張り状態で $\varepsilon_{2}<\varepsilon_{2}{ }^{\prime}<0$ であること, (2)たるみ領域では, $\varepsilon_{1}, \varepsilon_{2}, \varepsilon_{2}{ }^{\prime}$ は十分小さく, おおむ称 $0<\varepsilon_{1}$ であるが $\varepsilon_{1}<0$ の場合も存在する. なお，他文献(Zheng, 2009)に述心゙られているような， $\sigma_{2}$ の変動之 波しわの山谷との対応関係は見られなかった。

\section{$7 \cdot 1$ シミュレーション方法と結果}

\section{7. 強制面外変位による波しわ発生シミュレーション}

これまで説明してきたローラ偏角の増加による波しわ発生シミュレーションでは, 偏角が小さいと波しわは発 生せず，しわの情報が得られない，そこで，波しわが発生していない偏角で，ウェブに小さな面外変位を強制的 に加えて波しわを発生させる, 新たなシミュレーション法を構築した (強制面外変位法と呼ぶ)。この方法を 2 口 一ラモデルの Case B (5.1, 図 17) に適用して $\beta=0.25,1,2.5^{\circ}$ でしわ数 $n=7.5,6,4$ の波しわを得たが，本方法による 結果の妥当性を判断するには $\beta$ の範囲が狭いように思われた.

そこで，単純でかつ広い範囲の $\beta$ で波しわを発生しないモデルとして，図 21 に示寸ブロック・シートモデルを 考えた.このモデルは 1 個の剛体ブロックと膜要素で分割した矩形のシートからなる. 計算条件は先の 2 ローラ モデルの Case A とほぼ同じ（表 2 参照）で，張力による伸び歪分布の不整はあるが，シートの位置の不整は極め て小さく, このままでは張力付加時や偏角増加時に波しわは発生しない. このモデルによる計算中, いくつかの 偏角 $\beta$ で強制面外変位法を適用した，得られた波しわの例を図 $22(\mathrm{a}),(\mathrm{b}),(\mathrm{c})$ に示寸. これらは, $\beta=0,0.25,1^{\circ}$ のと きシートの・印の節点に，微小面外変位（y 方向変位） py を加えた時のしわの様子である. 1 節点に強制変位を 加えているためか，しわが久落している部分もあるが，シートの適当な位置で数えると，しわ数（明るい帯状の しまの数） $n$ が数えられる. こうしたシミュレーションを, $E=1 \mathrm{GPa}, 0.5 \mathrm{Gpa}$ について $\beta$ の広い範囲 $\left(\beta=0 \sim 8^{\circ}\right)$ で 行い，読み取ったしわ数 $n$ を図 23 に・印，×印で示した．図には，同じ条件での 2 ローラモデルの偏角増加時の しわ数変化を示す $n-\beta$ 線図 (図 14(b)の一部) も示してある. 図 23 より, 強制面外変位法による波しわの数 $n$ は, 先の図 14(b)の 2 ローラモデルの $n-\beta$ 線図にほぼ重なること, 図 14(b)では情報がなかった $\beta=0 \sim 0.5^{\circ}$ の・印， $\beta=0$ 〜2॰の×印のしわ数が新たに得られていることがわかる. これらの結果から, シート（ウェブ）のしわ数 $n$ は, 口 一ラ偏角 $\beta=0^{\circ}$ のときのしわ数 $n_{0}$ から, $\beta$ の増加とともに指数関数的に減少し，ある值 $n_{f}$ へ漸近しているように見 える. そこで, 次式で偏角 $\beta$ におけるしわ数 $n$ を推定することとし, その計算結果を図 23 に点線で示した.

$$
n=n_{f}+\left(n_{0}-n_{f}\right) \exp (-c \beta)
$$

ここで, $\beta$ は偏角を○で測った值, $n_{0}, n_{f}, c$ は各シミュレーションで異なる定数である. 図 23 では, $E=1 \mathrm{GPa}$ の場合, $n_{0}=12, n_{f}=3, \mathrm{c}=1, E=0.5 \mathrm{GPa}$ の場合, $n_{0}=13, n_{f}=4, c=0.7$ としている. 図より, 式(2)で計算した $n-\beta$ 線図は, これま で説明した 2 種類の波しわ発生シミュレーションの結果と比較的あっていると言える.

\section{$7 \cdot 2$ 座屈固有値解析の試み}

緒言で述べたように，シェル要素で分割した矩形膜（シート）の 1 軸引張りや純粋せん断によるしわの研究で は，座屈固有值解析が有用であることが知られている．本研究でも，2 ローラモデル（図 8）やブロック・シー トモデル（図 21）についてパワースイープ法で, 座屈固有值解析を行った，得られた座屈モードの中には，波し わとして妥当と思われるモードも存在したが, 張力や偏角の増加過程でこれらのモードが変化する様子や固有值 の意味を, 明確には把握できなかった. 図 24 にブロック・シートモデルの 3 次の座屈固有モードを示す. これに 対応する強制面外変位による波しわは図 22(a)である. 図22(a)では，中央右部分にしわの欠損があるが，どちら 
のしわもウェブの長手（x 軸）方向に平行で，しわ数 12 であり，よく似た結果になっている. 将来的には，本研 究で扱った 2 ローラモデルの偏角による波しわの解析を, 座屈固有值解析で系統的に行うことが望まれる.

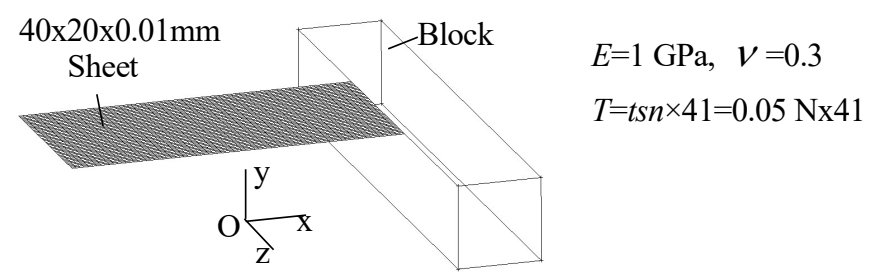

Fig.21 Block-sheet model

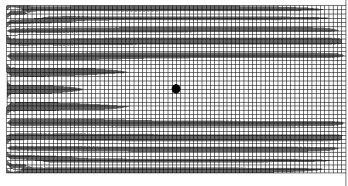

(a) $\beta=0^{\circ}, n=12, p y=0.02 \mathrm{~mm}$

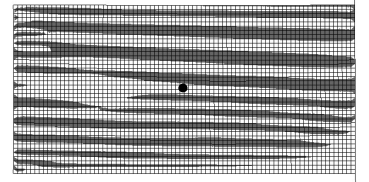

(b) $\beta=0.25^{\circ}, n=11, p y=0.02 \mathrm{~mm}$

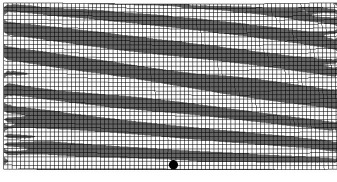

(c) $\beta=1^{\circ}, n=7, p y=0.1 \mathrm{~mm}$

Fig.22 These are the buckled wrinkling patterns of the sheet due to the forced out-of-plane displacement applied to the center or near edge node (marked by a small dot) of the sheet when the sheet is expanded and the supporting block inclines by the angle $\beta$. We can count the number of wrinkles $n$ on the sheet even though some parts of the wrinkles disappear due to the forced displacement. $n$ gradually decreases with increase in $\beta$.
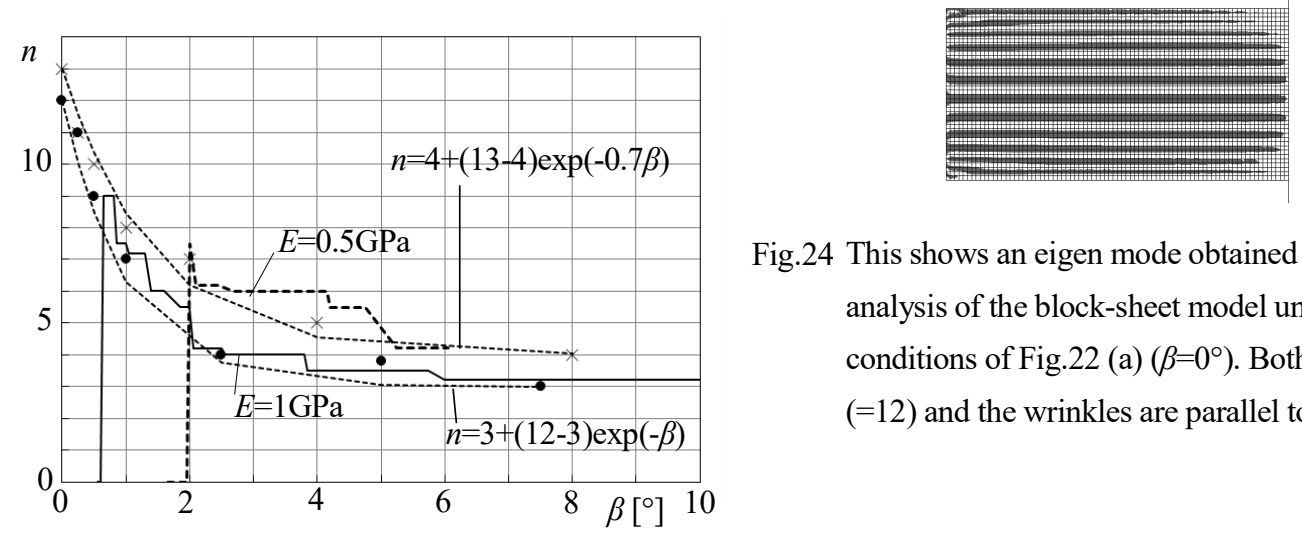

Fig.24 This shows an eigen mode obtained by the buckling analysis of the block-sheet model under the same conditions of Fig.22 (a) $\left(\beta=0^{\circ}\right)$. Both have the same $n$ $(=12)$ and the wrinkles are parallel to the sheet sides.

Fig.23 This figure includes (1) the $n-\beta$ curves (the solid line and bold dotted line) of Fig.14(b) obtained by 2 roller model, (2) the results $(\bullet$ and $\times$ ) of the block-sheet model buckled by the forced out-of-plane displacement and (3) the $n-\beta$ curves (the dotted curves) evaluated by Eq.(2). These three results are in good agreement. The results indicate the number of wavy wrinkles $n$ decreases exponentially from its initial value at $\beta=0$ as $\beta$ increases.

\section{8. 結 言}

ローラの傾き（偏角）でウェブに生じる波しわに関して，その発生と変化の過程を FEM 汎用解析ソフトでシ ミュレーションした．得られた結果を以下に要約する.

(1)ローラの偏角をゼロから増加させていくと，ある偏角でウェブに波しわが発生し，その後しわ数は減少しなが らある值へ漸近する．波しわの間隔，振幅，傾きはウェブの緩み側で大きく，張り側の側端で小さい. ローラ偏 角が増加すると, 多くの場合, これらのしわは間隔を広げながらウェブの側端へ向かって移動する. しわの傾き は最大主応力の方に一致し，しわの最大振幅は偏角とともに大きくなる，ローラ偏角が大きくなるとウェブの 緩み側にたるみ領域が生じ，しわの発生領域が狭められる。たるみ領域は von Mises 応力がある值（1 3 MPa）以 下の領域を囲むほぼ直角三角形の領域と考えられる. 
(2)ウェブに生じるしわ数は, 偏角ゼロの時の值から偏角の増加とともに指数関数的に減少する. ローラ偏角が同 じ場合，ウェブのヤング率や厚さが小さいほど，また，張力が大きいほど，しわ数は多い，ウェブのフリースパ ン長さやポアソン比はあまりしわ数の変化に影響しない. ウェブの幅方向分割数を増や寸と, しわ数は増加する.

(3)ウェブの寸法や物性值, 拘束条件, 張力などが与えられた場合, 特定のローラ偏角に達したとき波しわが発生 するのではなく, ウェブの歪（応力）分布やローラに対する位置など, 計算時の種々の不整（理想的な值からの ずれ）の大小によって, 波しわが発生するローラ偏角が決まると思われる. ウェブの歪分布や位置の不整が大き いと，比較的小さな偏角で波しわが発生する．これに対して，歪分布の不整が小さいと，大きな偏角になって波 しわが発生する．歪分布や位置の不整を十分小さくすると，波しわは発生しない.

(4)張力付加後, 偏角増加時におけるウェブの張り, しわ, たるみ状態での最大・最小主応力 $\sigma_{1}, \sigma_{2}$ の正負等は, 必ずしも従来の知見と一致しなかった. 例えば, $0<\sigma_{1}$ として, 従来は $\sigma_{2} \leq 0$ でしわ状態としているが, 本結果では, (a) $\sigma_{2}<0$ で張り状態のときがあり, また，(b) $\sigma_{2} \fallingdotseq 0$ (正負あり）でしわ状態のときがあった. また，従来は， $\sigma_{1} \leq 0$, $\sigma_{2} \leq 0$ でたるみ状態としているが，本結果では，(c) $\sigma_{1}, \sigma_{2} \doteqdot 0, \sigma_{l}>\sigma_{2}>0$ でたるみ状態であった．なお，最小主応力 の極大極小と波しわ変位の極大極小との間に対応関係は見られなかった.

\section{文献}

Cerda, E., Ravi-Chandar, K. and Mahadevan, L., Wrinkling of an elastic sheet under tension, Nature, Vol.419 (2002), pp. 579-580.

Cerda, E. and Mahadevan, L., Geometry and physics of wrinkling, Physical Review Letters, Vol.90, No.7 (2003), pp.1-4.

Diaby, A., Le van, A. and Wielgosz, C., Buckling and wrinkling of prestressed membranes, Finite Elements in Analysis and Design, Vol.42 (2006), pp. $992-1001$.

Eggen, P., Web handling : Top 7 Causes of Wrinkles, Paper, Film \& Foil Converter, Web/Roll Handling, October 10 (2011). available from <http://pffc-online.com/web-handling/9810-web-handling-top-7-causes-wrinkles-1010>, (参照日 2016 年 5 月 13 日).

Good, J. K., Kedl, D.M. and Shelton, J.J., Shear wrinkling in isolated spans, Proceedings of the $4^{\text {th }}$ International Conference on Web Handling (1997), pp.462-480.

Puntel, E., Deseri, L. and Fried, E., Wrinkling of a stretched thin sheet, J Elast (2011) 105:137-170, DOI 10.1007/s10659010-9290-5.

Rabinskiy, L.N., Shoumova, N.P. and Zhavoronok, S.I., Analytical Mechanics of Membrane Shells: a Review, Applied Mathematical Sciences, Vol. 10, No. 44 (2016), pp.2189-2204, available from $<\mathrm{http}: / / \mathrm{dx}$. doi.org/10.12988/ams.2016.64158>, (参照日 2016 年 8 月 29 日).

Roisum, D., Don't Wind Wrinkles into Your Film, Plastics Technology (2008), available from $<\mathrm{http}: / / \mathrm{www}$.ptonline.com/articles/dont-wind-wrinkles-into-your-film>, (参照日 2016 年 6 月 10 日).

Smith, R.D., The Ultimate Roll and Web Defect Troubleshooting Guide WITH GLOSSARY, Tappi Press (2013), ISBN 978-1-59510-229-9.

Tessler, A., Sleight, D. W. and Wang, J. T., Nonlinear shell modeling of thin membranes with emphasis on structural wrinkling, Proceedings of the 44th AIAA/ASME/ASCE/AHS/ASC Structures, Structural Dynamics and Materials Conference and Exhibit, 7-10 April 2003, Norfolk, VA. AIAA (2003)-1931.

Wong, Y.W. and Pellegrino, S., Amplitude of wrinkles in thin membranes. New approaches to structural mechanics, shells and biological structures, Kluwer Academic Publishers (2002), pp.257-270.

Wong, Y. W. and Pellegrino, S., Wrinkled membranes I: experiments, Journal of Mechanics of Materials and Structures, Vol.1, No.1 (2006a), pp.2-23.

Wong, Y. W. and Pellegrino, S., Wrinkled membranes II: analytical models, Journal of Mechanics of Materials and Structures, Vol.1, No.1 (2006b), pp.25-59.

Wong, Y. W. and Pellegrino, S., Wrinkled membranes III: numerical simulations, Journal of Mechanics of Materials and Structures, Vol.1, No.1 (2006c), pp.61-93. 
矢鍋重夫, 猪股和博, ローラ搬送されるフィルムのスキューおよびしわ発生シミュレーション，日本機械学会論 文集 C編, Vol.73, No.732 (2007), pp.2343-2349.

Zheng, L., Wrinkling of dielectric elastomer membranes. PhD Thesis, California Institute of Technology, Pasadena, California (2009).

\section{References}

Cerda, E., Ravi-Chandar, K. and Mahadevan, L., Wrinkling of an elastic sheet under tension, Nature, Vol.419 (2002), pp. 579-580.

Cerda, E. and Mahadevan, L., Geometry and physics of wrinkling, Physical Review Letters, Vol.90, No.7 (2003), pp.1-4.

Diaby, A., Le van, A. and Wielgosz, C., Buckling and wrinkling of prestressed membranes, Finite Elements in Analysis and Design, Vol.42 (2006), pp. $992-1001$.

Eggen, P., Web handling : Top 7 Causes of Wrinkles, Paper, Film \& Foil Converter, Web/Roll Handling, October 10 (2011). available from $<$ http://pffc-online.com/web-handling/9810-web-handling-top-7-causes-wrinkles-1010 $>$, (accessed on 13 May, 2016).

Good, J. K., Kedl, D.M. and Shelton, J.J., Shear wrinkling in isolated spans, Proceedings of the $4^{\text {th }}$ International Conference on Web Handling (1997), pp.462-480.

Puntel, E., Deseri, L. and Fried, E., Wrinkling of a stretched thin sheet, J Elast (2011) 105:137-170, DOI 10.1007/s10659010-9290-5.

Rabinskiy, L.N., Shoumova, N.P. and Zhavoronok, S.I., Analytical Mechanics of Membrane Shells: a Review, Applied Mathematical Sciences, Vol. 10, No. 44 (2016), pp.2189 - 2204, available from $<\mathrm{http}: / / \mathrm{dx}$.doi.org/10.12988/ams.2016.64158>, (accessed on 29 August, 2016).

Roisum, D., Don't Wind Wrinkles into Your Film, Plastics Technology (2008), available from $<$ http://www.ptonline.com/articles/dont-wind-wrinkles-into-your-film>, (accessed on 10 June, 2016).

Smith, R.D., The Ultimate Roll and Web Defect Troubleshooting Guide WITH GLOSSARY, Tappi Press (2013), ISBN 978-1-59510-229-9.

Tessler, A., Sleight, D. W. and Wang, J. T., Nonlinear shell modeling of thin membranes with emphasis on structural wrinkling, Proceedings of the 44th AIAA/ASME/ASCE/AHS/ASC Structures, Structural Dynamics and Materials Conference and Exhibit, 7-10 April 2003, Norfolk, VA. AIAA (2003)-1931.

Wong, Y.W. and Pellegrino, S., Amplitude of wrinkles in thin membranes. New approaches to structural mechanics, shells and biological structures, Kluwer Academic Publishers (2002), pp.257-270.

Wong, Y. W. and Pellegrino, S., Wrinkled membranes I: experiments, Journal of Mechanics of Materials and Structures, Vol.1, No.1 (2006a), pp.2-23.

Wong, Y. W. and Pellegrino, S., Wrinkled membranes II: analytical models, Journal of Mechanics of Materials and Structures, Vol.1, No.1 (2006b), pp.25-59.

Wong, Y. W. and Pellegrino, S., Wrinkled membranes III: numerical simulations, Journal of Mechanics of Materials and Structures, Vol.1, No.1 (2006c), pp.61-93.

Yanabe, S. and Inomata, K., Simulation on skew and folded wrinkle of film transferred by misaligned roller, Transactions of the Japan Society of Mechanical Engineers, Series C, Vol.73, No.732 (2007), pp.2343-2349 (in Japanese).

Zheng, L., Wrinkling of dielectric elastomer membranes. PhD Thesis, California Institute of Technology, Pasadena, California (2009). 